GEOHYDROLOGY OF THE NORTHERN PART OF THE TOWN OF BROOKHAVEN, SUFFOLK COUNTY, NEW YORK

by Edward J. Koszalka

U.S. GEOLOGICAL SURVEY

Water-Resources Investigations Report 83-4042

Prepared in cooperation with the

SUFFOLK COUNTY DEPARTMENT OF HEALTH SERVICES and SUFFOLK COUNTY WATER AUTHORITY

Syosset, New York

1984 


\section{UNITED STATES DEPARTMENT OF THE INTERIOR}

WILLIAM P. CLARK, Secretary

GEOLOGICAL SURVEY

Dallas L. Peck, Director

For additional information write to:

U.S. Geological Survey

5 Aerial Way

Syosset, New York 11791

Telephone: (516) 938-8830
Copies of this report may be purchased from:

Open-File Services Section Western Distribution Branch U.S. Geological Survey Box 25425, Federal Center Denver, Colorado 80225 Telephone: (303) 234-5888 
Abstract. . . . . . . . . . . . . . . . . . . . 1

Introduction. . . . . . . . . . . . . . . . . . . . . . 1

Purpose and scope ...................... 2

Methods of investigation. . . . . . . . . . . . . . 2

Acknowledgments . . . . . . . . . . . . . . . 3

Physical setting. ......................... 3

Location and extent of area ............... 3

Previous investigations.................. 3

Population. . . . . . . . . . . . . . . . 4

Land use. . . . . . . . . . . . . . . . . . 5

Water use.................... . . 6

Geology ............................... 7

Stratigraphy. . . . . . . . . . . . . . . . . . 7

Bedrock. ...................... 10

Raritan Formation. . . . . . . . . . . . . . 11

Magothy Formation and Matawan Group, undifferentiated. . . . 14

Pleistocene deposits . . . . . . . . . . . . . . . 14

Holocene deposits. .................. 15

Geologic history. . . . . . . . . . . . . . . . 15

Hydrology . . . . . . . . . . . . . . . . . . . . . 16

Hydrologic system . . . . . . . . . . . . . . . 16

Precipitation. . . . . . . . . . . . . . . 16

Surface water. . . . . . . . . . . . . . . . 19

Recharge and discharge of ground water . . . . . . . 19

Upper glacial aquifer. . . . . . . . . . . . . . 21

Magothy aquifer. . . . . . . . . . . . . 23

Lloyd aquifer. . . . . . . . . . . . . . . . 24

Water quality . . . . . . . . . . . . . . . 24

Summary and conclusions . . . . . . . . . . . . . . . . 27

References cited.......................... 28

\section{PLATES}

(in pocket)

Plate 1-5. Maps of the northern part of the Town of Brookhaven showing:

1. Location of wells, streamflow-measurement sites, and hydrogeologic sections.

2. Altitude of top of Magothy Formation and Matawan Group, undifferentiated.

3. Generalized surficial geology.

4. Water-table altitude in April 1980.

5. Potentiometric surface of the Magothy aquifer in April 1980. 


\section{ILLUSTRATIONS}

Page

Figure 1. Map showing major geographic features of Long Island and location of the northern part of the Town of Brookhaven and of Setauket weather station. . . . . . . . . 2

2. Map showing location of areas used to describe the variation in population in the northern part of the Town of

Brookhaven ..................... 5

3. Generalized geologic section in the northern part of the Town of Brookhaven ................... 7

4-6. Maps of northern part of the Town of Brookhaven showing:

4. Altitude of bedrock surface. . . . . . . . . 11

5. Altitude of top of Lloyd Sand Member of the Raritan Formation. . . . . . . . . . .... 12

6. Altitude of top of clay member of the Raritan Formation. ................ 13

7-8. Graphs of precipitation at Setauket, 1930-79:

7A. Annual precipitation. . . . . . . . . . 17

7B. Average monthly precipitation .......... 17

8A. Yearly departures from mean annual precipitation. . 18

8B. Cumulative departure from mean annual precipitation - 18

9. Twenty-year hydrograph for we11s S3870, S3871, S3955, and S6413....................... . . 22

10. Hydrogeologic sections:

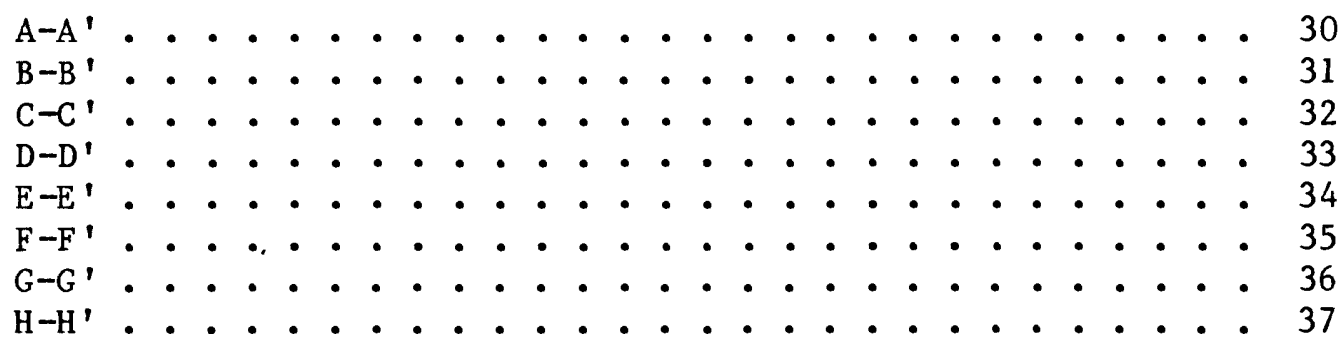




\section{TABLES}

Page

Table 1. Population of the northern part of the Town of Brookhaven. . 4

2. Estimated public-supply withdrawals by private water companies in the northern part of the Town of Brookhaven,

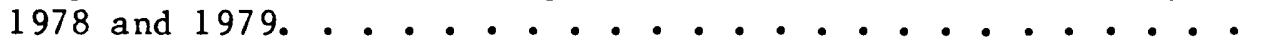

3. Estimated public-supply withdrawals by Suffolk County Water Authority in the northern part of the Town of Brookhaven, 1978 and 1979....................

4. Summary of geologic and hydrogeologic units in the northern part of the Town of Brookhaven . . . . . . . . . 10

5. Discharge measurements of selected streams in the northern part of the Town of Brookhaven, 1978-80. . . . . . . . 20

6. Chemical analyses of ground water from observation we1ls screened in the upper glacial aquifer in the northern part of the Town of Brookhaven, 1978 . . . . . . . . . . . 25

7. Chemical analyses of ground water from public-supply wells in the northern part of the Town of Brookhaven, 1978. . . . . 26 


\section{Conversion Factors and Abbreviations}

\begin{tabular}{|c|c|c|}
\hline Inch-pound unit & Multiply by & To obtain SI ${ }^{1}$ units \\
\hline inch (in) & 25.4 & millimeter $(\mathrm{mm})$ \\
\hline foot $(f t)$ & 0.3048 & meter $(m)$ \\
\hline mile (mi) & 1.61 & kilometer $(\mathrm{km})$ \\
\hline square mile $\left(\mathrm{mi}^{2}\right)$ & 2.59 & square kilometer $\left(\mathrm{km}^{2}\right)$ \\
\hline ga11on (gal) & 3.785 & liter (L) \\
\hline million gallons (Mgal) & 3785 & cubic meter $\left(\mathrm{m}^{3}\right)$ \\
\hline $\begin{array}{l}\text { gallon per minute } \\
\text { (gal/min) }\end{array}$ & $6.309 \times 10^{-5}$ & $\begin{array}{l}\text { cubic meter per second } \\
(\mathrm{m} 3 / \mathrm{s})\end{array}$ \\
\hline $\begin{array}{l}\text { gallon per minute per foot } \\
{[(\mathrm{ga} 1 / \mathrm{min}) / \mathrm{ft}]}\end{array}$ & $2.07 \times 10^{-4}$ & $\begin{array}{l}\text { cubic meter per second per } \\
\text { meter }\left[\left(\mathrm{m}^{3} / \mathrm{s} / \mathrm{m}\right)\right]\end{array}$ \\
\hline foot per day $(\mathrm{ft} / \mathrm{d})$ & 0.3048 & meter per day $(\mathrm{m} / \mathrm{d})$ \\
\hline $\begin{array}{l}\text { foot squared per day } \\
\left(f t^{2} / d\right)\end{array}$ & 0.0929 & $\begin{array}{l}\text { meter squared per day } \\
\qquad\left(\mathrm{m}^{2} / \mathrm{d}\right)\end{array}$ \\
\hline $\begin{array}{l}\text { gallon per day per foot } \\
(\mathrm{gal} / \mathrm{d}) / \mathrm{ft}\end{array}$ & 0.0124 & $\begin{array}{l}\text { meter squared per day } \\
\qquad\left(\mathrm{m}^{2} / \mathrm{d}\right)\end{array}$ \\
\hline--- & -- & $\underset{(\mathrm{mg} / \mathrm{L})}{\operatorname{mil1igram} \text { per liter }}$ \\
\hline micromho ( $\mu$ mho) & 1 & $\begin{array}{l}\text { microsiemen per centimeter } \\
\text { at } 25^{\circ} \text { Celsius }(\mu \mathrm{S} / \mathrm{cm} \text { at } \\
\left.25^{\circ} \mathrm{C}\right)\end{array}$ \\
\hline
\end{tabular}

National Geodetic Vertical Datum of 1929 (NGVD of 1929): A geodetic datum derived from a general adjustment of the first-order level nets of both the United States and Canada, formerly called mean sea level. NGVD of 1929 is referred to as sea level in this report.

International System of Units. 


\title{
GEOHYDROLOGY OF THE NORTHERN PART OF THE TOWN OF BROOKHAVEN, SUFFOLK COUNTY, NEW YORK
}

\author{
By Edward J. Koszalka
}

\begin{abstract}
The ground-water resources of the northern part of the Town of Brookhaven, Suffolk County, N.Y., were investigated from September 1977 through September 1980. The area studied encompasses 130 square miles in north-central Suffolk County.

Bedrock in the area consists of metamorphosed Paleozoic rock overlain by Cretaceous, Pleistocene, and Holocene deposits. The surficial material consists of late Wisconsin morainal and outwash deposits in association with recent beach and marsh deposits.

Precipitation is the only source of ground water in the region. of the average annual precipitation of 44.4 inches, about 21.5 inches reaches the ground-water reservoir. Average overland runoff is estimated to be about 0.5 inch per year, and average annual evapotranspiration is estimated to be 22.4 inches per year.

Total public water-supply pumpage in the area in 1979 was estimated to be $23.2 \mathrm{Mga} / \mathrm{d}$ (million gallons per day). Of this total, $15.8 \mathrm{Mgal} / \mathrm{d}$ was withdrawn from the upper glacial aquifer and $7.4 \mathrm{Mgal} / \mathrm{d}$ from the Magothy aquifer; the Lloyd aquifer was not used for water supply.

Average hydraulic conductivity ranges from 100 to 300 feet per day in the upper glacial aquifer and from 50 to 70 feet per day in the Magothy aquifer. Transmissivity ranges from 25,000 to 105,000 feet squared per day in the upper glacial aquifer and from 13,000 to 41,000 feet squared per day in the Magothy aquifer. Only sparse data are available for the Lloyd aquifer; average hydraulic conductivity and transmissivity are estimated to be 40 feet per day and 10,000 feet squared per day, respectively.

In general, ground water in the area is of suitable quality for drinking and most other uses. Some constituents, however, particularly iron, chloride, and nitrogen, occur locally in unacceptably high concentrations.
\end{abstract}

\section{INTRODUCTION}

Ground water is the sole source of water for public-supply, industrial, agricultural, and commercial use in central and eastern Long Island. This area has undergone extensive eastward urbanization since the 1950 's, and the need for the ground-water resources has increased accordingly. To facilitate proper development and management of this resource amid population growth and commercial development, the geohydrologic environment and its chemical characteristics must be thoroughly understood. 


\section{Purpose and Scope}

The northern part of the Town of Brookhaven, which occupies the central part of Suffolk County ( $f$ ig. 1), is expected to undergo continued growth during the coming decades. Therefore, if the water resource is to be properly managed to meet this growth, it is necessary to examine and understand ground-water occurrence, movement, and quality.

The U.S. Geological Survey studied the water resources of the area and compiled and evaluated available data from October 1976 through September 1980. The study was done in cooperation with Suffolk County Department of Health Services and Suffolk County Water Authority.

This report presents a series of maps and tables summarizing hydrologic and geologic data related to occurrence and movement of ground water in the area of investigation. Included are a water-table map of the upper glacial aquifer, a potentiometric-surface map of the Magothy aquifer, generalized surficial-geology and structure-contour maps, and cross sections with geologic logs. Also included are precipitation graphs, a summary of pumpage data, and hydrographs of selected wells. These data are to be used in future regional modeling studies.

\section{Methods of Investigation}

Observation wells suitable for water-level measurements and water-quality sampling were inventoried, and 17 additional wells were drilled to improve the observation-we11 network. These additional wells (p1.1) are those having

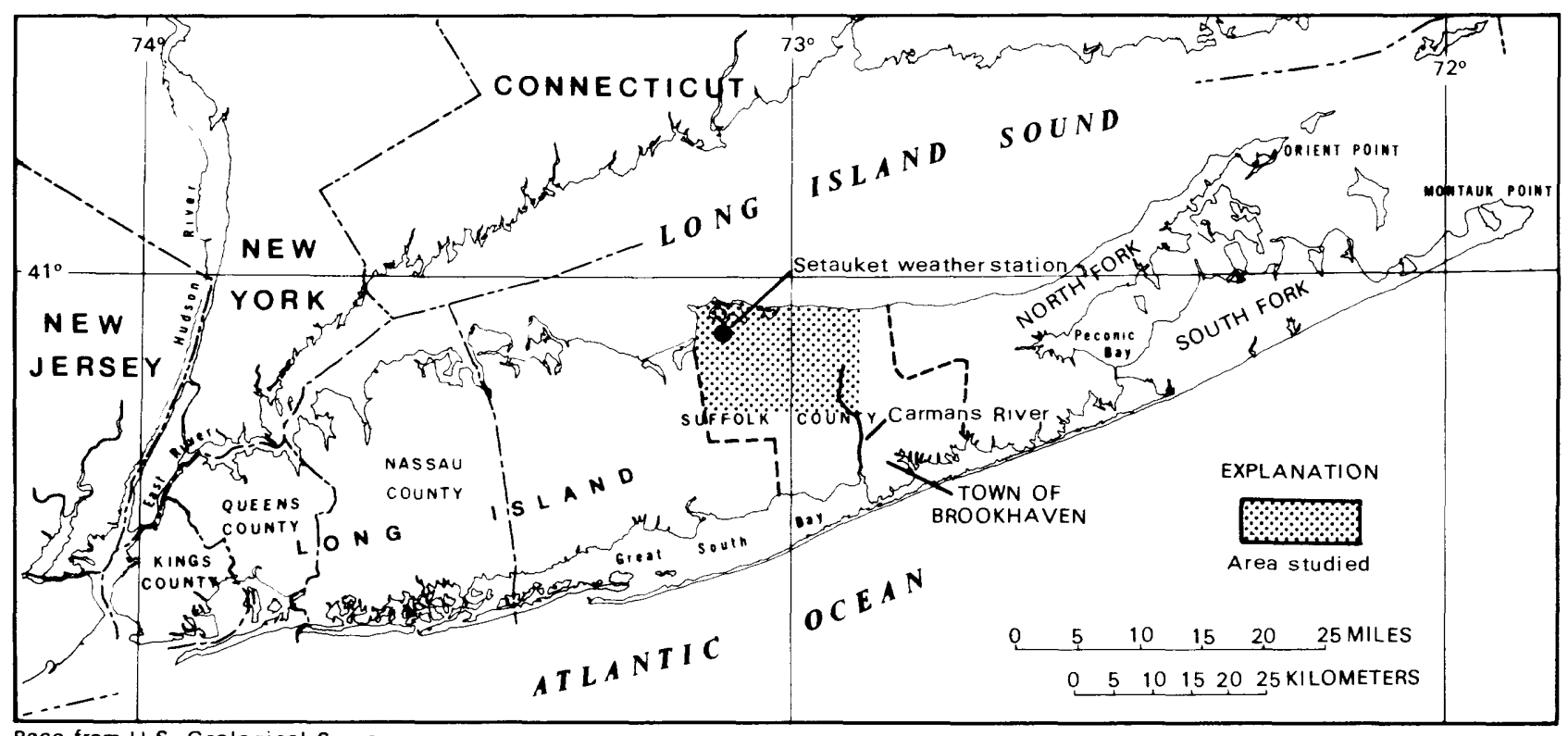

Base from U.S. Geological Survey

State base map, 1:500,000, 1974

Figure 1.-Major geographic features of Long Island and location of the northern part of the Town of Brookhaven and of Setauket weather station, Suffolk County, New York. 
we11 numbers greater than 62000. Locations of all hydrologic data sites are shown in plate 1 .

Ground-water levels in the upper glacial (water-table) aquifer were measured from April 1976 through September 1980. Water-level data from 50 observation wells measured in April 1980 were used to make a water-table map (p1. 4), and water-level data from 18 wells screened in the underlying Magothy aquifer were used to make a potentiometric-surface map (p1. 5). A11 we 11 measurements were adjusted to sea level to uniformly define the water-table and potentiometric-surface altitudes.

Ground-water and surface-water samples were analyzed for physical and chemical properties. The analyses included water from 61 wells screened in the upper glacial aquifer, 27 wells screened in the Magothy aquifer, and seven stream sites (Koszalka, 1980, tables 3-7). The analyses were made by the U.S. Geological Survey, the Suffolk County Department of Environmental Contro1 (now part of the Suffolk County Department of Health Services), and the Suffolk County Water Authority.

Eight cross sections are shown in figure 10 (at end of report); their locations are shown in plate 1 . Several test holes were drilled to better define the top of the Magothy Formation and Matawan Group, undifferentiated, and to delineate the configuration and depth of a buried channel of Pleistocene age ( $\mathrm{p} 1.2)$.

Public-supply pumpage in the study area during 1971-77 is given in Koszalka (1980); public-supply pumpage for 1978 and 1979 are given in tables 2 and 3 .

\section{Acknowledgments}

The author acknowledges the cooperation and assistance of the Suffolk County Water Authority and the Suffolk County Department of Health Services in data collection and laboratory services for the chemical analyses of water samples. Appreciation is also extended to the New York State Department of Environmental Conservation for their collection of public-supply data. Also, appreciation is extended to State and municipal officals, well drillers, and private individuals who supplied additional information used in the preparation of the report.

\section{PHYSICAL SETTING}

\section{Location and Extent of Area}

The northern part of the Town of Brookhaven occupies about $130 \mathrm{mi}^{2}$ in north-central Suffolk County between $72^{\circ} 53^{\prime}$ and $73^{\circ} 10^{\prime} \mathrm{W}$. 1ongitude and $40^{\circ} 48^{\prime}$ and $40^{\circ} 49^{\prime} \mathrm{N}$. latitude (fig. 1). The area is bounded on the north by the Long Island Sound; the other boundaries are shown in plate 1.

\section{Previous Investigations}

The geology of the northern part of the Town of Brookhaven was first studied by Fullex (1914); his report describes the Pleistocene units and includes a surficial geologic map. The subsurface geology was presented by 
Suter, delaguna, and Perlmutter (1949). Other investigators who have described the geology of the area are Holzmacher, McLendon, and Murrell (1968) and Jensen and Soren (1974).

The most recent water-table maps that include the area are by Kimmel (1971) for 1970; Koszalka and Koch (1974) and Jensen and Soren (1974) for 1971; Vaupel and others (1977) for 1972; Koszalka (1975) for 1974; Nakao and Ehrlichman (1978) for 1975; and Koszalka (1980) for 1979. In addition to these maps, the Suffolk County Department of Health Services has prepared yearly water-table maps for the entire county since 1977.

Additional publications concerning the hydrology of the area are Cohen, Franke, and McClymonds (1969) for the 1962-66 drought; Koch and Koszalka (1973) and Vaupel and others (1977) for the 1972 potentiometric surface of the Magothy aquifer; Prince (1976) for the 1975 potentiometric surface of the Magothy aquifer; and Koszalka (1980) for the 1979 potentiometric surface of the Magothy aquifer. Some of the streamflow and water-quality data presented in this report have been published by the U.S. Geological Survey (1978, 1979, 1980).

\section{Population}

Total population of the northern part of the Town of Brookhaven in 1978 is estimated to have been 213,450 (Long Island Lighting Co., 1978). To calculate the population, the study area was divided into four smaller areas (fig. $2)$; the resulting estimates for 1960, 1970, and 1978 are listed in table 1.

During 1960-78, population increased nearly 300 percent in the study area. The estimated residential population density in 1960 was 0.66 per acre and by 1978 had increased to 2.57 per acre. These estimates do not include the part-time residents and tourists, who increase the total population and water demands during summer. Their numbers are unknown, however.

Table 1. Population of the northern part of the Town of Brookhaven.

\begin{tabular}{lccc}
\hline \multirow{2}{*}{ Area (see fig. 2) } & \multicolumn{2}{c}{ Census } & $\begin{array}{c}\text { Estimated population } \\
\text { January 1, 1978 }\end{array}$ \\
\hline I Port Jefferson - Stony Brook & 13,040 & 44,800 & 48,330 \\
II Lake Grove - Selden & 28,720 & 78,620 & 98,930 \\
III Rocky Point - Mount Sinai & 6,600 & 18,960 & 36,380 \\
IV Yaphank - Ridge & $\underline{6,250}$ & $\underline{14,800}$ & 29,810 \\
\hline
\end{tabular}

Data from Long Island Lighting Co., 1978 


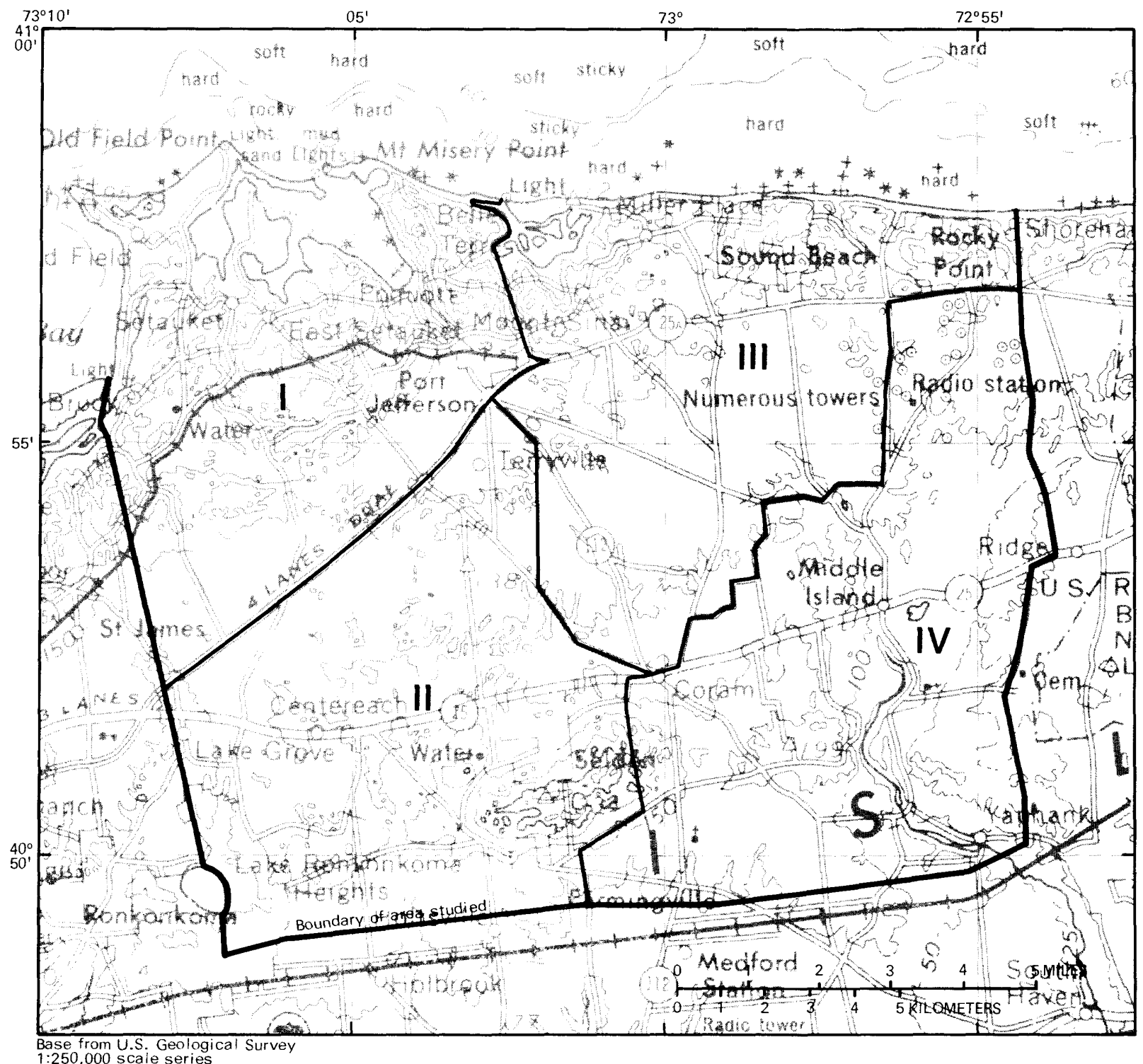

Figure 2.--Areas used to describe the variation in population of the northern part of the Town of Brookhaven, Suffolk County, N.Y. General location is shown in figure 1.

\section{Land Use}

Land in the northern part of the town is divided among several uses-principaliy housing, recreation, and agriculture, with smaller allotments for commercial and industrial use, transportation, and utilities. Residential use predominates in the western and northern parts of the area; recreational and agricultural use predominate in the eastern and southern parts. The recreational lands consist of beaches and parks; the agricultural lands are mainly sod farms, orchards, shrub and tree nurseries, and farms growing crops such as corn, cauliflower, and cabbage. Commercial and industrial land use is restricted to areas adjacent to the major roads. 


\section{Water Use}

Public-supply and industrial water is obtained from the upper glacial (water-table) aquifer and the underlying Magothy aquifer; no water is obtained from the Lloyd (deep) aquifer in this area. At present, the northern part of the Town of Brookhaven is served by seven private water companies and the Suffolk County Water Authority. The private companies supply about 11,000 service units solely from the upper glacial aquifer. Their total pumpage is less than 5 percent of the total public-supply pumpage. Table 2 gives the total pumpage from the aquifer by these companies in 1978 and 1979; table 3 (pp. 8-9) gives the total pumpage by the Suffolk County Water Authority, which taps the upper glacial and Magothy aquifers, during the same years. (Locations of public-supp1y wells are shown in $\mathrm{p} 1.1$. )

Total public-supply withdrawal in the area in 1979 is estimated to have been $23.2 \mathrm{Mgal} / \mathrm{d}$. The upper glacial aquifer is the major source for public water supply; in $1979,15.8 \mathrm{Mgal} / \mathrm{d}$ was withdrawn from it and $7.4 \mathrm{Mgal} / \mathrm{d}$ from the Magothy aquifer.

Water is also used for irrigation. Although pumpage for farm and golf-course irrigation is unknown, it is estimated to be less than $0.5 \mathrm{Mgal} / \mathrm{d}$, a11 from the upper glacial aquifer.

Table 2. Estimated public-supply withdrowals by private water companies in the northern part of the Town of Brookhaven, 1978 and 1979.

[Records from New York State Department of Environmental Conservation]

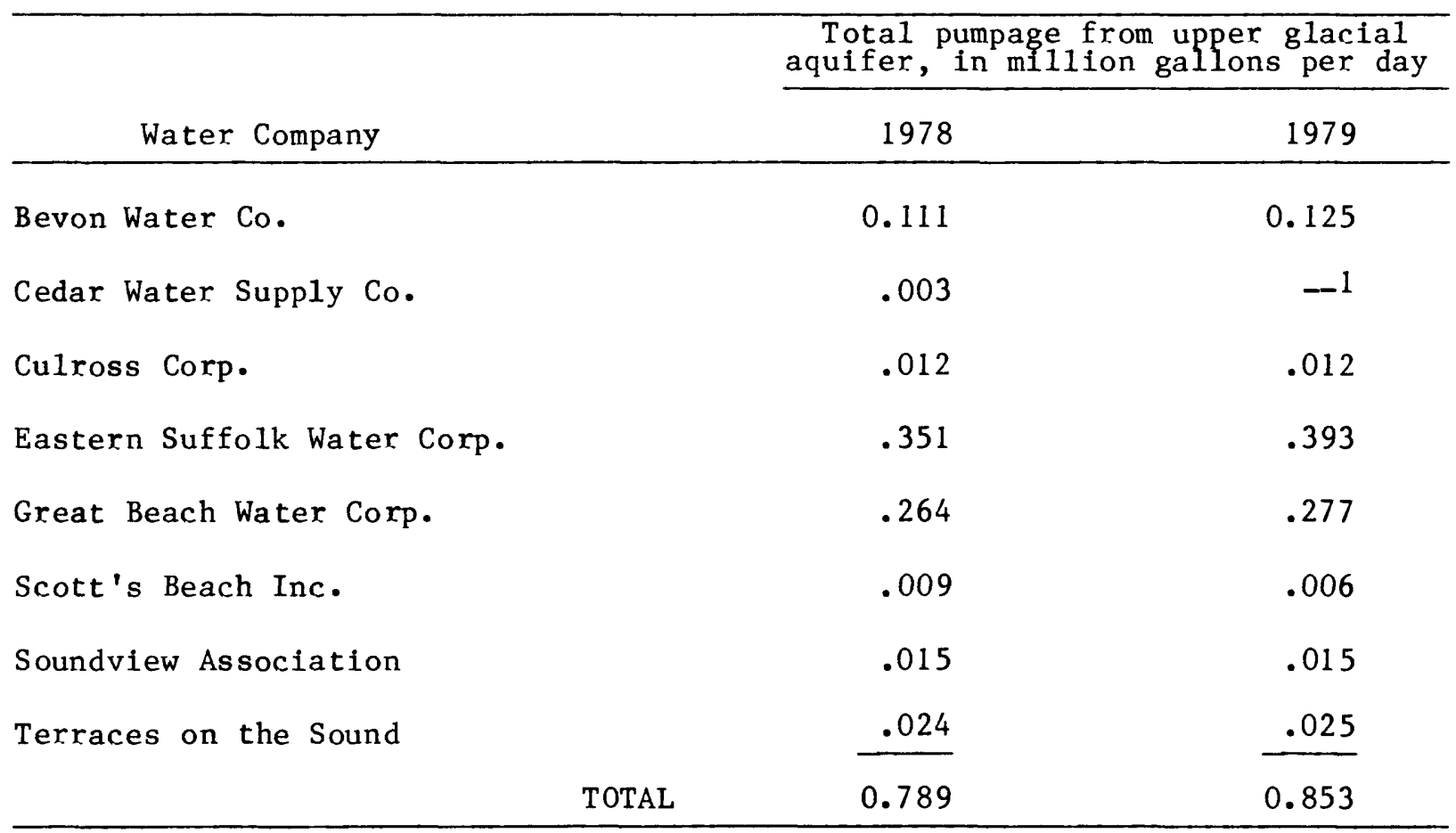

1 All services have been taken over by the Suffolk County Water Authority. 
The two major aquifers are capable of producing considerably more than the $23.2 \mathrm{Mgal} / \mathrm{d}$ currently being withdrawn and are the most likely to be developed for additional supplies, as inferred from current ground-water quantity and quality. Withdrawal from the Lloyd aquifer is restricted by New York State to supplying water to the south-shore barrier islands of Long Island and to other areas with specific supply problems.

\section{GEOLOGY}

\section{Stratigraphy}

The northern part of the Town of Brookhaven is underlain by unconsolidated deposits that rest unconformably on the metamorphosed Paleozoic basement complex (fig. 3). The unconsolidated deposits are Cretaceous and Quaternary in age. The Cretaceous deposits belong to the Raritan Formation and the overlying Magothy Formation and Matawan Group, undifferentiated. The Raritan Formation, which consists of the Lloyd Sand Member and an overlying clay member, is continuous throughout the area; the Magothy Formation and Matawan Group, undifferentiated, has been eroded by glacial meltwater that left channels in the northern part of the area.

Overlying the Cretaceous formations are Quaternary deposits consisting of several glacial, periglacial, and interglacial units including a marine clay and the Smithtown clay (informal usage). Surficial units consist of outwash, morainal, shore, beach, and salt-marsh deposits. Table 4 (p. 10) summarizes the geologic units and the corresponding hydrogeologic units in the northern part of the Town of Brookhaven.

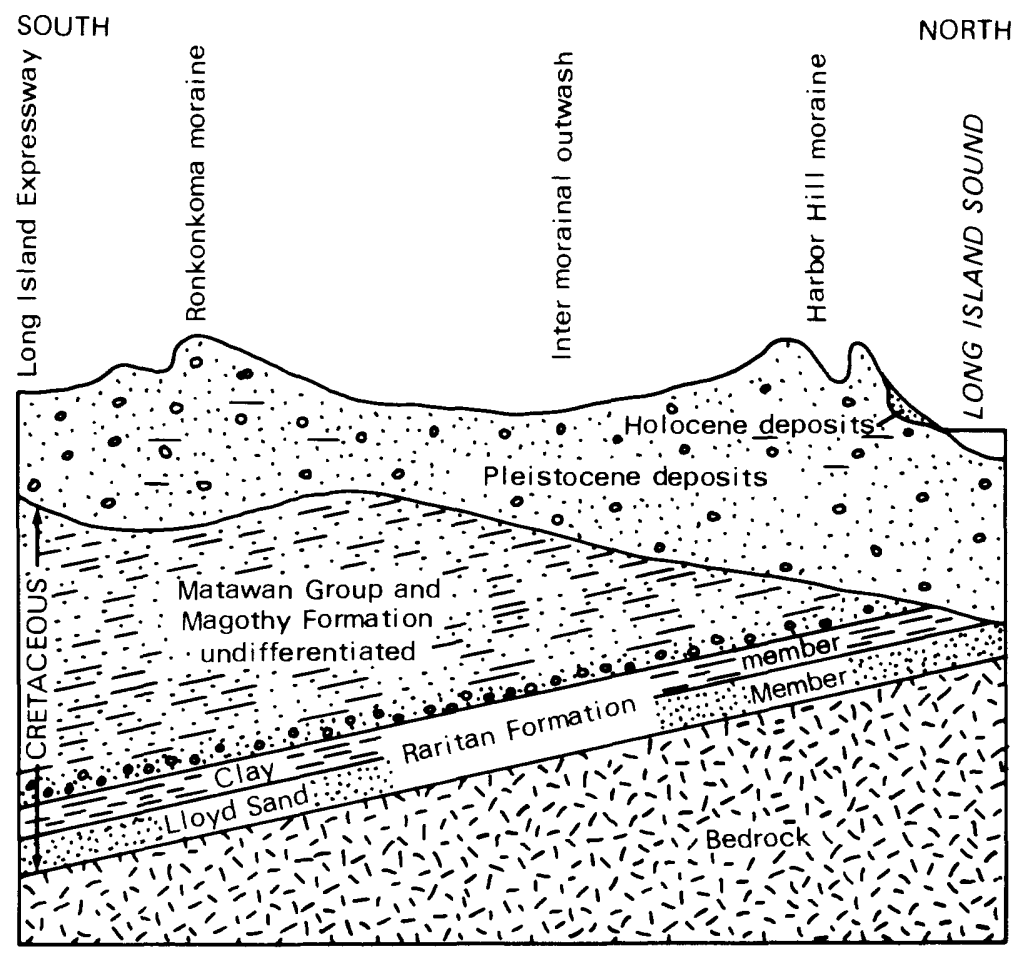

\section{EXPLANATION}

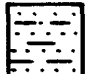

Sandy clay, clayey sand, and silt
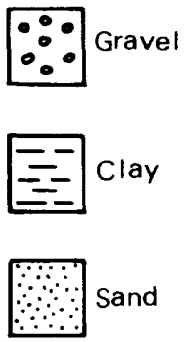

Consolidated rock

Figure 3.--Generalized geologic section in the northern part of the Town of Brookhaven, Suffolk County, New York. (From Koszalka, 1980, p. 5.) 


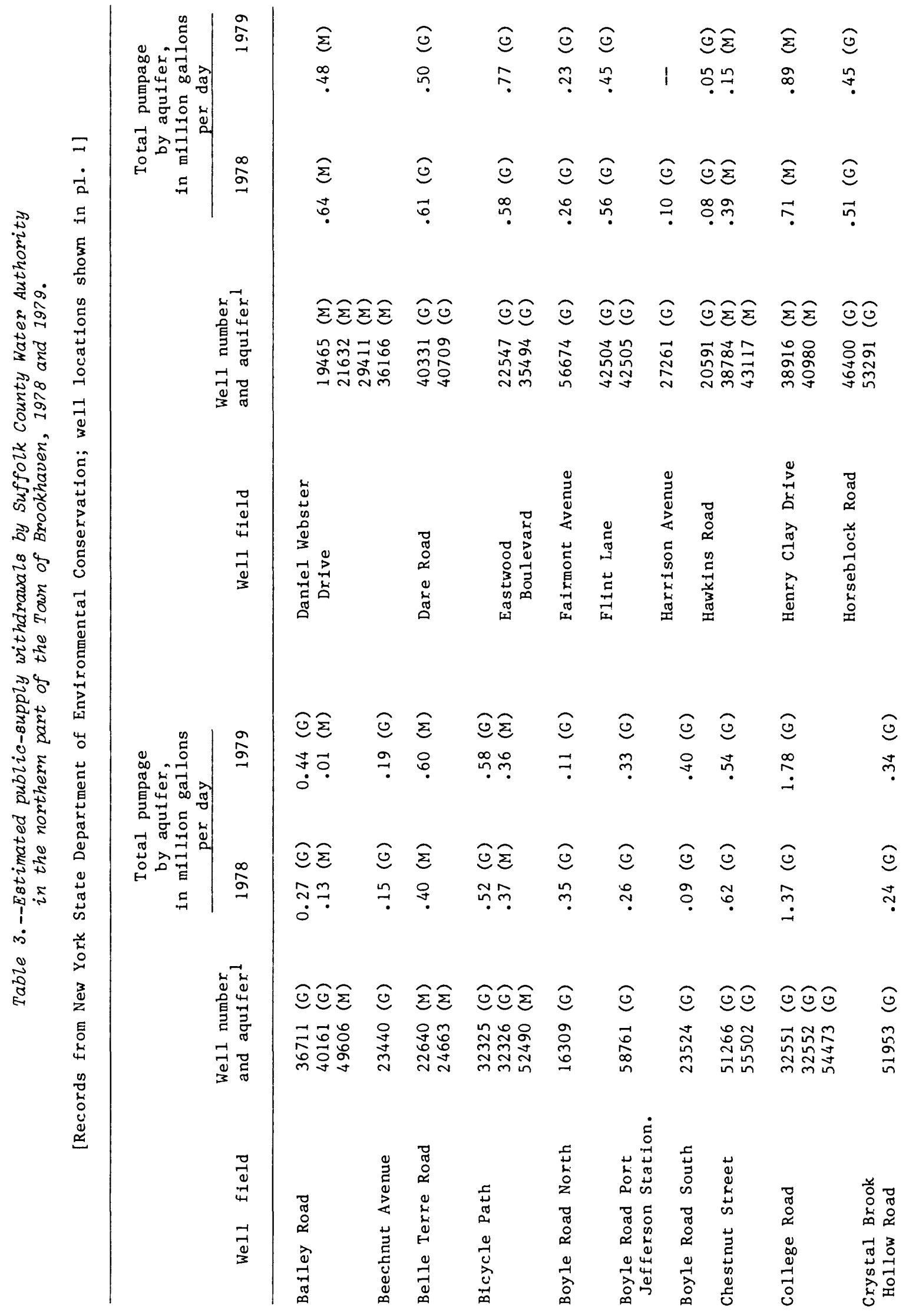




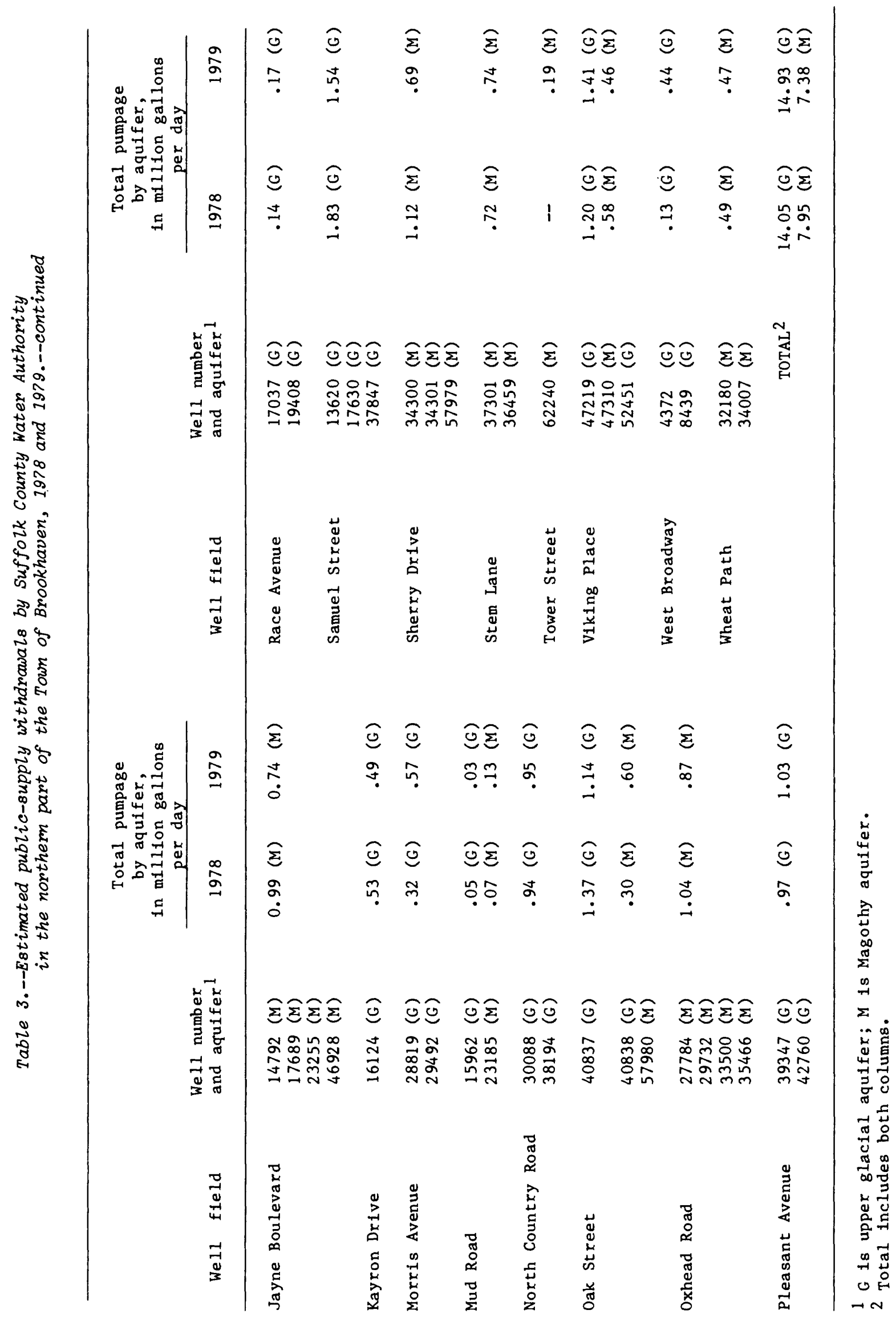


Table 4.--Summary of geologic and hydrogeologic units in the northern part of the Town of Brookhaven.

\begin{tabular}{|c|c|c|c|}
\hline System & Series & Geologic unit & $\begin{array}{c}\text { Hydrogeologic } \\
\text { unit }\end{array}$ \\
\hline \multirow{3}{*}{ Quaternary } & Holocene & $\begin{array}{l}\text { Recent shore, beach, and } \\
\text { salt-marsh deposits }\end{array}$ & \multirow{2}{*}{$\begin{array}{c}\text { Upper glacial } \\
\text { aquifer }\end{array}$} \\
\hline & \multirow[t]{2}{*}{ Pleistocene } & $\begin{array}{l}\text { Moraine deposits } \\
\text { Glaciofluvial deposits } \\
\text { Smithtown clay (informal } \\
\text { usage) }\end{array}$ & \\
\hline & & $\begin{array}{l}\text { Gardiners Clay } \\
\text { Marine clay }\end{array}$ & $\begin{array}{l}\text { Gardiners } \\
\text { Clay } \\
\text { Marine clay }\end{array}$ \\
\hline \multirow{2}{*}{ Cretaceous } & \multirow{2}{*}{$\begin{array}{c}\text { Upper } \\
\text { Cretaceous }\end{array}$} & $\begin{array}{l}\text { Matawan Group and } \\
\text { Magothy Formation, } \\
\text { undifferentiated }\end{array}$ & $\begin{array}{l}\text { Magothy } \\
\text { aquifer }\end{array}$ \\
\hline & & $\begin{array}{ll}\text { Raritan } & \text { Unnamed clay } \\
\text { Formation } & \\
& \begin{array}{l}\text { Lloyd Sand } \\
\text { Member }\end{array}\end{array}$ & $\begin{array}{l}\text { Raritan } \\
\text { confining unit } \\
\text { Lloyd aquifer }\end{array}$ \\
\hline $\begin{array}{c}\text { Paleozoic } \\
\text { and/or } \\
\text { Precambrian (?) }\end{array}$ & & Bedrock & Bedrock \\
\hline
\end{tabular}

Bed rock

Two test borings in the northern part of the Town of Brookhaven (wells S33379T and S31734T) extend to bedrock. (See hydrogeologic sections A-A' and C-C' in fig. 10, at end of report.) Jensen and Soren (1974) constructed a map of the bedrock surface which indicates that depth to bedrock increases to the south from less than $700 \mathrm{ft}$ to more than $1,400 \mathrm{ft}$ below sea level (fig. 4).

Bedrock at well S33379T is deeply weathered gneiss with quartzitic and biotite banding; that at $531734 \mathrm{~T}$ is a weathered gneiss. 


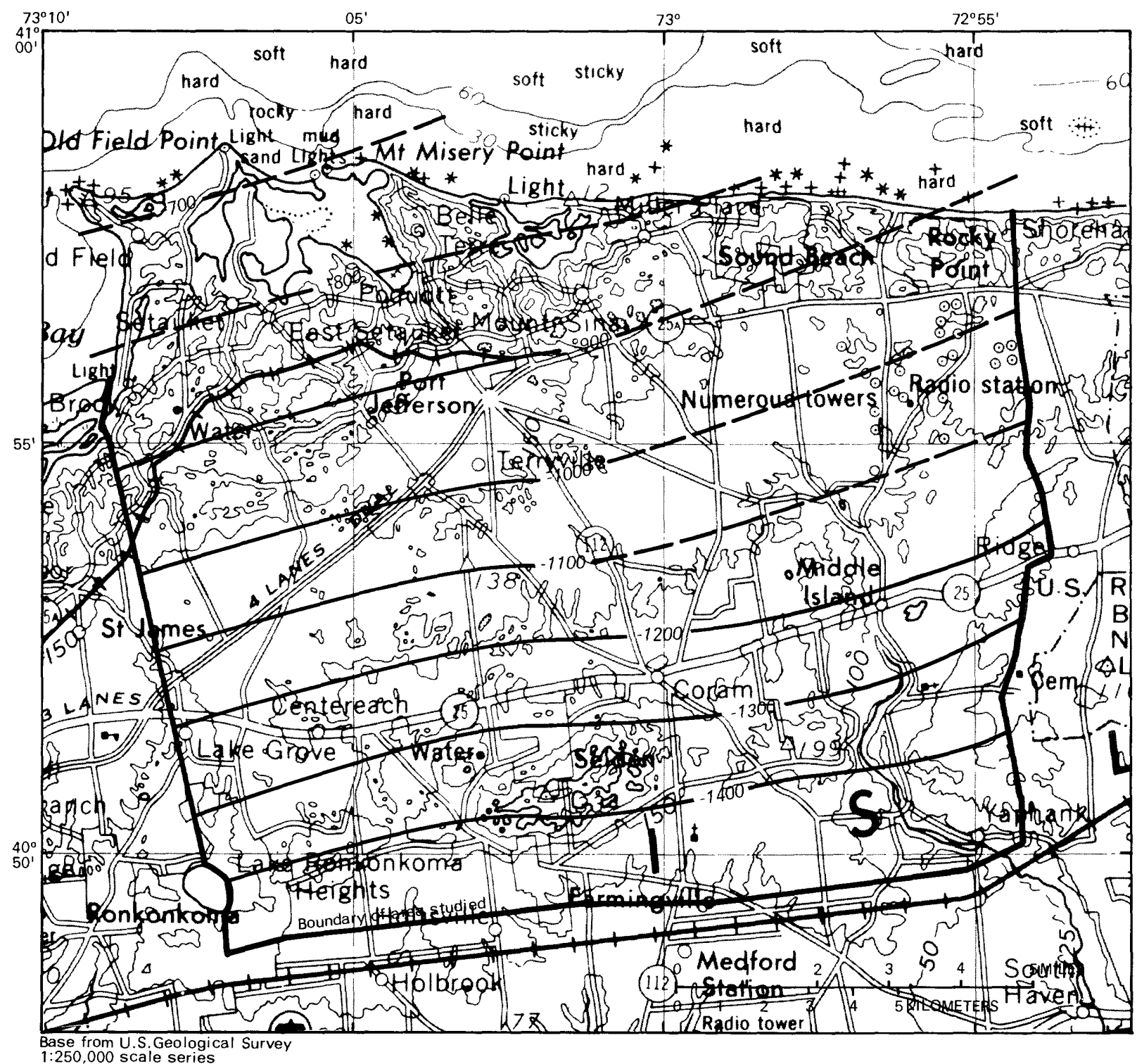

Figure 4.--Altitude of bedrock surface in the northern part of the Town of Brookhaven, Suffolk County, N.Y. (From Jensen and Soren, 1974, sheet 1).

\section{Raritan Formation}

The Raritan Formation of Late Cretaceous age consists of the Lloyd Sand Member, which overlies bedrock, and an unnamed clay member that overlies the Lloyd Sand Member (fig. 3). The Raritan Formation, which is continuous throughout Long Island, is correlative with the Raritan Formation of New Jersey. Two test holes have penetrated the Raritan Formation in the northern part of the Town of Brookhaven--S33379T and $\$ 31734 \mathrm{~T}$ (fig. 10, sec. $A-A^{\prime}$ and $\left.\mathrm{B}-\mathrm{B}^{\prime}\right)$. 
A map showing the altitude of the top of the Lloyd Sand Member in Suffolk County was prepared by Jensen and Soren (1974); a part of that map representing the study area is shown in figure 5. The altitude of the top of the Lloyd Sand Member decreases southward from about 500 to $1,200 \mathrm{ft}$ below sea level. The unit has an estimated thickness of $200 \mathrm{ft}$. Core samples from test holes S33379T and S31734T, which penetrate the unit, are composed of a fine, lightgray sand with streaks of clay and some lignite.

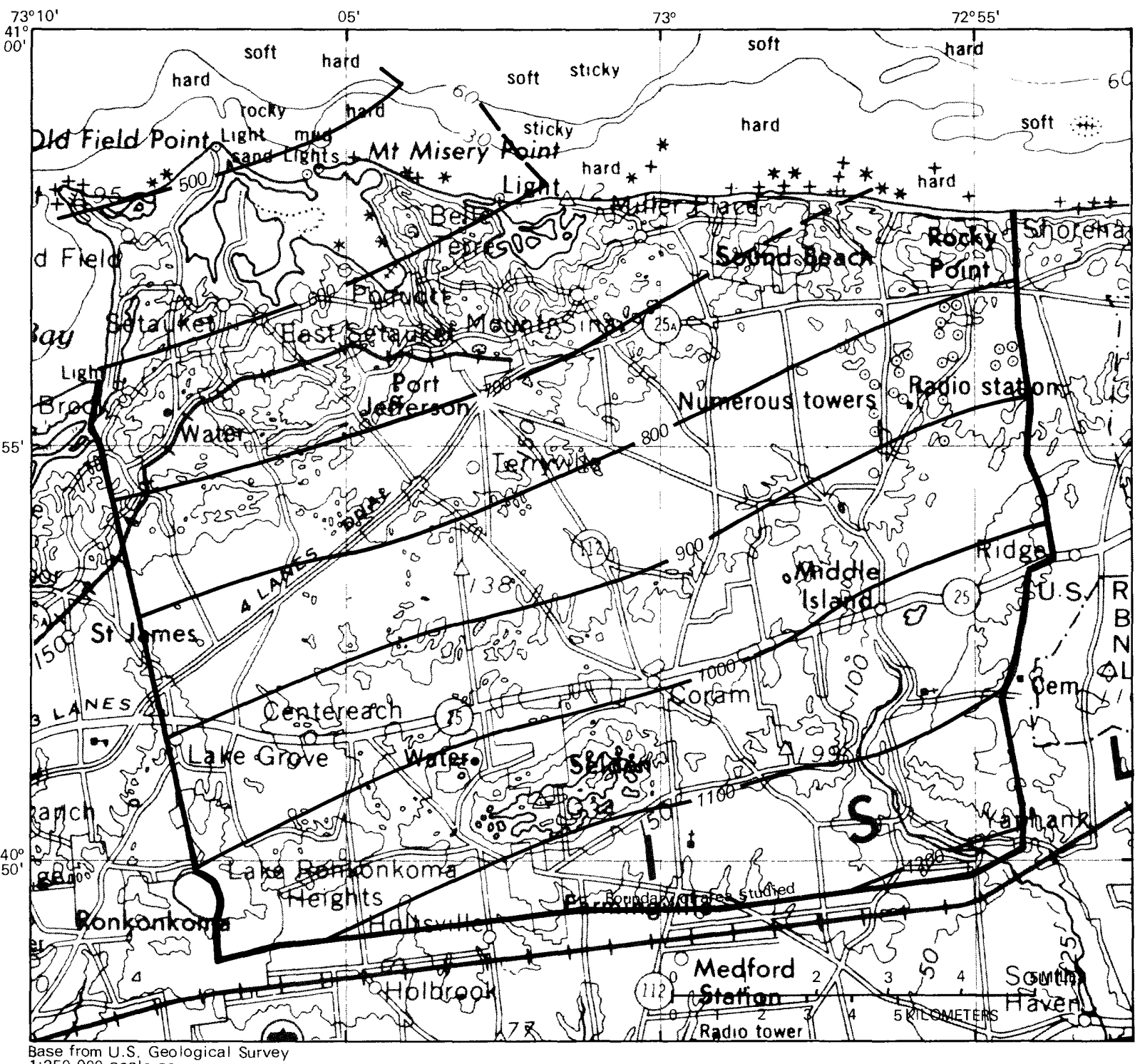

Base from U.S, Geologica

Figure 5.--Altitude of top of Lloyd Sand Member of the Raritan Formation in the northern part of the Town of Brookhaven, Suffolk County, N.Y. (From Jensen and Soren, 1974, sheet 1). 
A map showing the altitude of the top of the unnamed clay member in Suffolk County is included in Jensen and Soren (1974) also; the variation in altitude in the study area is indicated in figure 6 . The top of the clay member decreases in altitude southeastward from about 400 to $1,000 \mathrm{ft}$ below sea level. The clay member has an estimated thickness of $150 \mathrm{ft}$.

The term "clay member" is misleading; although the unit contains many layers of clay, it also includes layers of fine to coarse sand and some gravel, lignite, and pyrite.

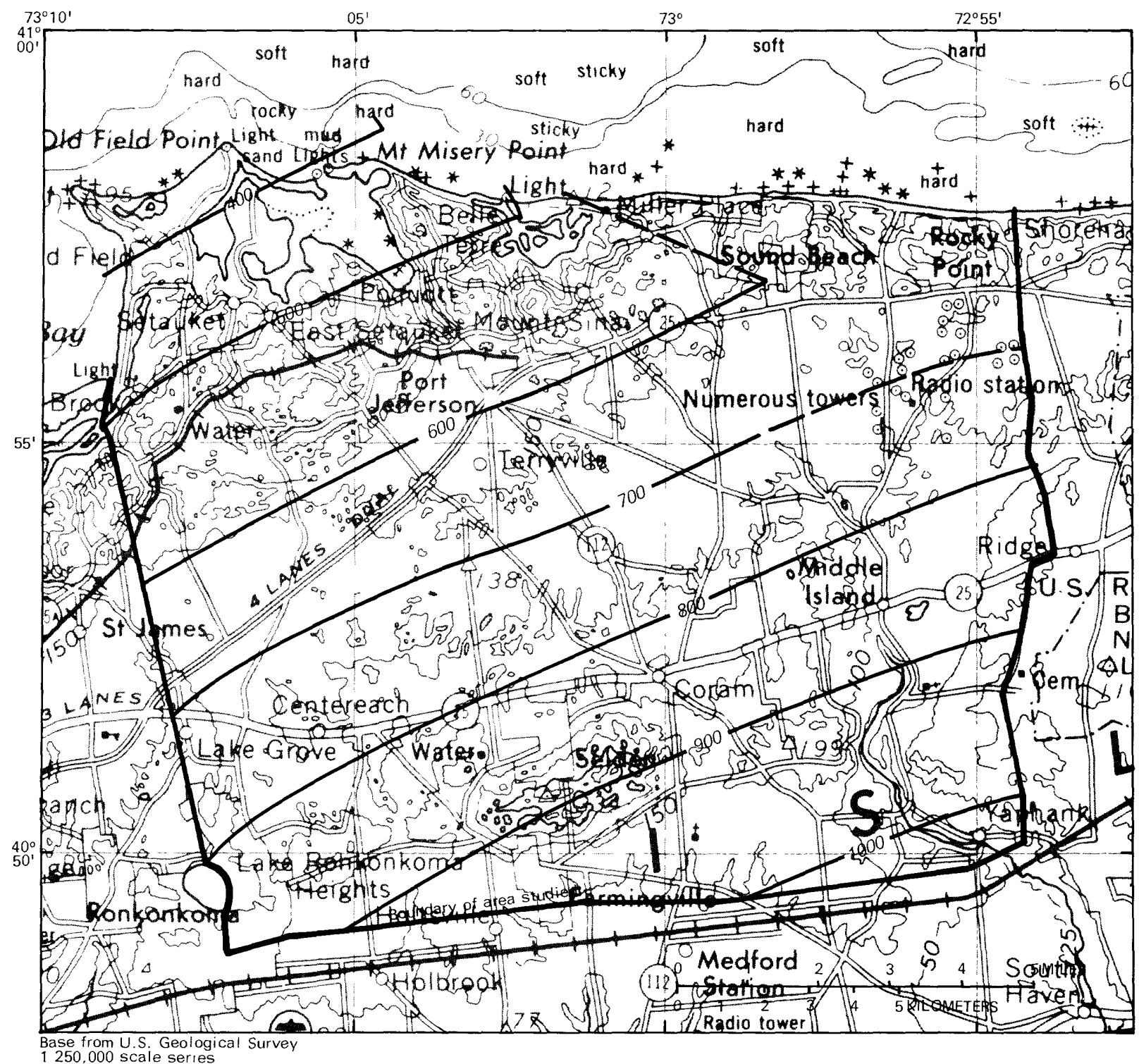

Figure 6.--Altitude of top of clay member of the Raritan Formation in the northern part of the Town of Brookhaven, Suffolk County, N.Y. (From Jensen and Soren, 1974, sheet 1). 


\section{Magothy Formation and Matawan Group, Undifferentiated}

The Magothy Formation is Late Cretaceous in age and overlies the Raritan Formation. It is unconformably overlain by Pleistocene deposits (fig. 3 ).

The altitude of the top of the Magothy and Matawan sequence in the area is shown in plate 2. The contours differ from those published in Jensen and Soren (1974); recent test-hole data indicate a channel, more than $600 \mathrm{ft}$ below sea level in the central part of the area, that extends north to the limit of the Magothy and Matawan sequence as defined by Jensen and Soren. Beyond this limit, the Magothy and Matawan sequence was eroded by glacial activity, and subsequent Pleistocene deposits unconformably overlie the Raritan Formation. The channel is bounded on the northwest, west, and south by surface highs of Magothy and Matawan deposits having an altitude of less than $100 \mathrm{ft}$ below sea level. The thickness of the Magothy Formation ranges from greater than $900 \mathrm{ft}$ in the southern part of the area to less than $100 \mathrm{ft}$ in the vicinity of the channel.

The Magothy Formation and Matawan Group, undifferentiated, consists of beds of poorly sorted quartzose sand interbedded with silt and clay. The clay beds are as thick as $40 \mathrm{ft}$ and are discontinuous. Lignite, pyrite and marcasite are commonly found throughout the formation.

\section{Pleistocene Deposits}

Pleistocene deposits consisting of morainal and glaciofluvial (outwash) sediments unconformably overlie the Magothy Formation and Matawan Group, undifferentiated. Two clay units interfinger these sediments--the marine Gardiners Clay in the lowermost glacial deposits, formed during an interstadial or an interglacial period, and, higher in the section, a nonmarine intermorainal clay informally called the Smithtown clay, formed by the meltwaters of the Harbor Hill end moraine ( 1.3 ).

Morainal and glaciofluvial sediments form most of the surficial deposits of the area studied. They consist of the Ronkonkoma terminal moraine, the Harbor Hill end moraine, ground moraine, and outwash deposits (p1.3). The morainal deposits are primarily foreset beds of sand and gravel with occasional lenses of till and clay. Many of the sand and gravel deposits are folded or faulted as a result of slumping.

South of the Ronkonkoma moraine is an outwash plain that slopes gently southward to the Great South Bay (fig. 1). This glaciofluvial deposit consists of stratified fine to coarse tan sand that contains fine to medium gravel. Cross bedding is common in these deposits. Between the Ronkonkoma terminal moraine and the Harbor Hill end moraine lies a second glaciofluvial deposit, a thin outwash plain deposited by the meltwaters of the Harbor Hill end moraine. In some localities it overlies the Smithtown clay.

The contact between morainal and glaciofluvial deposits is almost undetectable because they are nearly identical lithologically. An approximate contact was drawn on plate 3 to differentiate these deposits. 
The Gardiners Clay extends through the southern part of the study area. It was found in three test holes--S60127T, S56674 and S63967T (see hydrogeologic sections $D_{-} \mathrm{D}^{\prime}$ and $\mathrm{H}^{-\mathrm{H}^{\prime}}$ in fig. 10). It consists of a gray to a grayishgreen sandy clay. The color variation reflects the glauconite content. (Glauconite is a green iron silicate mineral of the mica group.) The presence of glauconite suggests a slow deposition rate. The fossil content of the unit ranges locally from a few diatoms and foraminifera to no fossils.

The age of this unit is speculative. It could have been deposited during an interstade between the formation of Ronkonkoma and Harbor Hill moraines, or it could been deposited during the Sangamon Interglaciation.

The so-called Smithtown clay of this report is similar to the "clay unit of Smithtown" described by Lubke (1964). It lies roughly between the Ronkonkoma and Harbor Hill moraines and ranges from brown to gray and from clay to sandy clay. Geologic data to define its extent and thickness are lacking, however.

\section{Holocene Deposits}

Recent deposits consisting of beach and marsh sediments are found most1y along the coast of the study area (p1. 3). The beach deposits consist of sand and gravel with some boulders; the material is derived from erosion of the bluffs to form spits. The marsh deposits, which consist of clay, silt, sand and organic matter, are generally restricted to the tidal zones.

\section{Geologic History}

During the Cretaceous Period, 138 million to 63 million years ago, sediments were transported from highlands north of Long Island and deposited upon the bedrock. These deposits formed the Raritan and Magothy Formations.

During the Tertiary Period, 63 million to 2 million years ago, deposition of sediments throughout Long Island either ceased or was followed by erosion.

From 2 million to 10,000 years ago, during the Pleistocene Epoch, the Magothy Formation was eroded by channeling, and glacial material was deposited over it. As sea level fluctuated during interglacial and interstadial periods, the Gardiners Clay was deposited at highstand. In a late Wisconsin interstade, a proglacial lake formed north of the Ronkonkoma terminal moraine in which the Smithtown clay was deposited.

With the final recession of continental glaciers during late Wisconsin glaciation, 25,000 to 10,000 years ago, sea level rose, and parts of the glacial deposits were eroded or inundated. Some of these eroded sediments were then redeposited to form the present beach material. 


\section{HYDROLOGY \\ Hydrologic System}

Precipitation is the sole source of freshwater in central and eastern Long Island. Thus, the amount of precipitation determines the amount of water available for use. Some of the precipitation evaporates on land, some is absorbed by plants, then transpired back into the atmosphere, and some flows overland to streams. The remainder, about 50 percent of the initial quantity, infiltrates to the water table to become ground water. The ground water in turn moves seaward and eventually discharges either into streams flowing to the Long Island Sound or Great South Bay (fig. 1), or discharges directly to these bodies of water as subsea outflow.

The thickness and areal extent of the three aquifers that constitute the ground-water reservoir of the northern part of the Town of Brookhaven are shown in hydrogeologic sections $\mathrm{A}^{-\mathrm{A}^{\prime}}$ to $\mathrm{H}-\mathrm{H}$ ' (fig. 10).

\section{Precipitation}

The northern part of the Town of Brookhaven has a temperate marine climate that is influenced by the Atlantic Ocean and Long Island Sound. Precipitation falls in almost the same total amount during the cool season as during the warm season, but storms are less severe and more frequent in the cool season. Most precipitation on Long Island is in the form of rain; only 5 to 10 percent is in the form of snow or sleet.

Long-term precipitation in Suffolk County averages 43 inches per year, as determined from 30 years of records collected by the National Weather Service.

The precipitation regime of Long Island for 1951-65 was studied by Miller and Frederick (1969), who calculated the mean annual precipitation in the northern part of the Town of Brookhaven to be between 44 and 50 inches. The larger amount occurs in the southern part of the area and gradually decreases northward toward the Long Island Sound.

The annual precipitation recorded at Setauket (fig. 1) from 1930-79 ranged from a maximum 56.50 inches in 1975 to a minimum 26.55 inches in 1965 (fig. 7A); the long-term average annual precipitation from 1930-79 is 44.44 inches. Mean monthly precipitation at Setauket from 1930-79 ranges from a low of 3.26 inches in February to a high of 4.27 inches in November ( $\mathrm{fig} .7 \mathrm{~B}$ ).

Yearly departures and a cumulative departure from the mean annual precipitation are depicted in figure 8. In general, annual precipitation was below mean annual precipitation during 1962-71 and was above the average yearly during 1953-62 and 1971-79. 

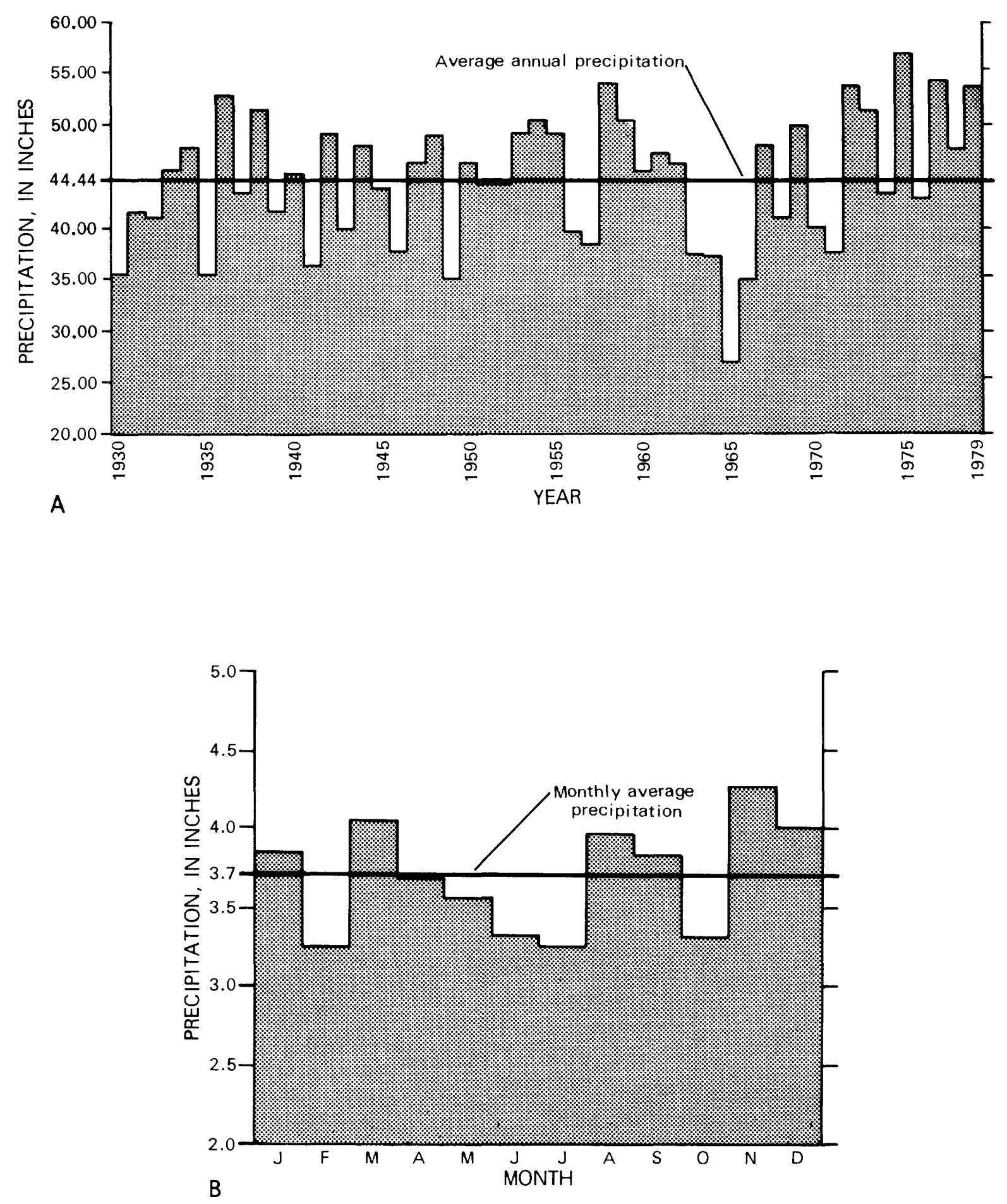

Figure 7.--Precipitation at Setauket, Suffolk County, N.Y., 1930-79.

$A$, annual precipitation; $B$, mean monthly precipitation.

(Location is shown in fig. 1; data from National Weather Service.) 

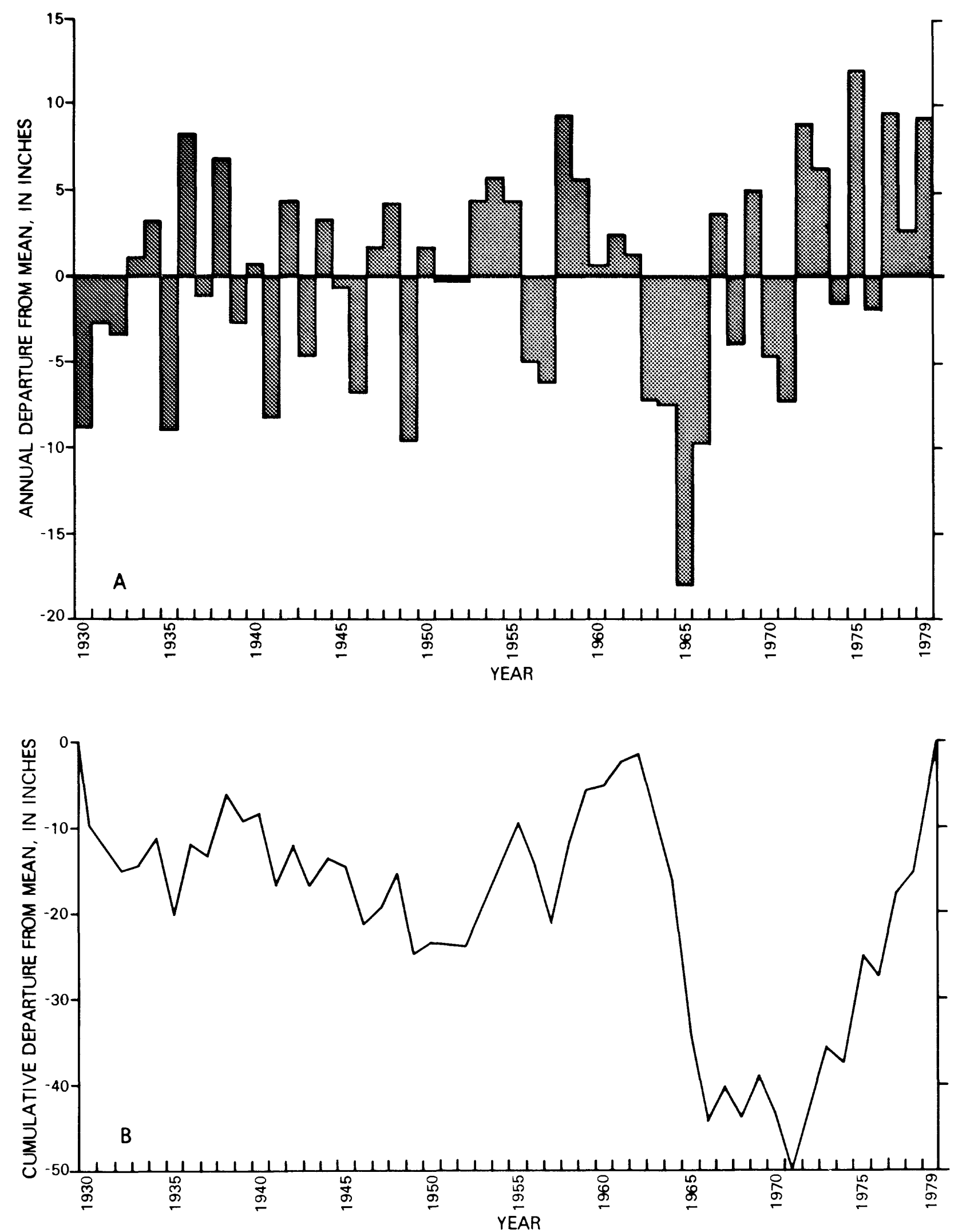

Eigure 8.--Yearly departures from mean annual precipitation at setauket, 1930-79. A, annual departures; $B$, cumulative departure.

(Location is shown in fig. 1; data from National Weather Service.) 


\section{Surface Water}

Al1 streams within the area studied except Carmans River flow northward into the Long Island Sound; Carmans River flows south into the Great South Bay (fig. 1). The area also contains several natural lakes and ponds; many are kettle holes that intersect the water table, and some are perched. In addition, several ponds have been created behind small dams on some of the streams.

Stream discharge was measured periodically at base flow as a measure of ground-water discharge at seven sites in the northern part of the Town of Brookhaven; the locations of these sites are shown in plate 1. Koszalka (1980, table 2) presented discharge measurements of the streams during 1977-78; table 5 gives the stream-discharge measurements for these sites during 1978-80. The U.S. Geological Survey maintains a continuous gaging station on Carmans River south of the study area; daily discharge rates from 1942 to the present are available from the Survey's Long Island office.

\section{Recharge and Discharge of Ground Water}

Ground water in the northern part of the Town of Brookhaven is recharged by infiltration of precipitation through the soils to the water table. The quantity of water that reaches the water table varies throughout the year and annually. Several factors control the amount of recharge; these include variations in precipitation, the stratigraphy and soil characteristics of the area, and rate of evapotranspiration--the natural loss of water through both evaporation and transpiration by plants.

Evapotranspiration could not be measured directly in this study; therefore, all calculations must be considered estimates. Bart and others (1976), using the Thornthwaite Water Balance Calculation, calculated the average annual evapotranspiration for $1930-75$ on Long Island to be 23.2 inches. Vaupel and others (oral commun., 1977), using the method of Thornthwaite and Mather (1957), calculated the average annual evapotranspiration for 1956-73 for Nassau County and western Suffolk County to be 21.6 inches. The average of these two values (22.4 inches) is considered representative of the Brookhaven area.

Average values for precipitation, evapotranspiration, and overland runoff can be used in equation 1 to estimate average recharge:

$$
\text { recharge }=\text { precipitation - (evapotranspiration + overland runoff) }
$$

From an average annual precipitation value of 44.4 inches, an estimated average annual evapotranspiration rate of 22.4 inches, and an average overland runoff value of 0.5 inches, recharge can be estimated as shown below:

$$
\text { recharge }=44.4-(22.4+0.5)=21.5 \mathrm{in} / \mathrm{yr}
$$

Ground water is discharged into the bays, harbors, and Long Island Sound through several streams along the north shore of the study area, and also into Carmans River basin, in the southeastern part of the area (fig. 1 ). In 
Table 5.--Discharge measurements of selected streams in the northerm part of the Town of Brookhaven, 1978-80.

[Site locations are shown in figure 2]

\begin{tabular}{|c|c|c|c|c|}
\hline $\begin{array}{l}\text { Station } \\
\text { no. }\end{array}$ & Station name & Location & Date & $\begin{array}{c}\text { Discharge } \\
\left(\mathrm{ft}^{3} / \mathrm{s}\right)\end{array}$ \\
\hline 01304051 & $\begin{array}{l}\text { Stony Brook at } \\
\text { Stony Brook. }\end{array}$ & $\begin{array}{l}\text { Lat } 40^{\circ} 54^{\prime} 53^{\prime \prime} \text {, long } 73^{\circ} 08^{\prime} 52^{\prime \prime} \text {, } \\
\text { Suffolk County, } 100 \mathrm{ft} \text { down- } \\
\text { stream from Harbor Road, at } \\
\text { Stony Brook. }\end{array}$ & $\begin{array}{r}10-25-78 \\
4-12-79 \\
8-22-79 \\
11-8-79 \\
7-15-80 \\
9-15-80\end{array}$ & $\begin{array}{l}2.5 \\
4.5 \\
4.0 \\
3.1 \\
2.1 \\
3.2\end{array}$ \\
\hline 01304060 & $\begin{array}{l}\text { Unnamed Tributary to } \\
\text { Conscience Bay at } \\
\text { Setauket. }\end{array}$ & $\begin{array}{l}\text { Lat } 40^{\circ} 56^{\prime} 49^{\prime \prime}, \text { long } 73^{\circ} 07^{\prime} 01^{\prime \prime} \text {, } \\
\text { Suffolk County, } 30 \mathrm{ft} \text { down- } \\
\text { stream from pond below 01d } \\
\text { Field Road, at Setauket. }\end{array}$ & $\begin{array}{r}10-25-80 \\
4-12-79 \\
8-22-79 \\
11-8-79 \\
7-15-80 \\
9-15-80\end{array}$ & $\begin{array}{l}2.0 \\
2.7 \\
2.2 \\
1.6 \\
3.7 \\
1.6\end{array}$ \\
\hline 01304065 & $\begin{array}{l}\text { Unnamed Tributary to } \\
\text { Setauket Harbor at } \\
\text { East Setauket. }\end{array}$ & $\begin{array}{l}\text { Lat } 40^{\circ} 56^{\prime} 35^{\prime \prime} \text {, long } 73^{\circ} 06^{\prime} 08^{\prime \prime} \\
\text { Suffolk County, at culvert } \\
\text { on State Highway } 25 \mathrm{~A} \text {, at } \\
\text { East Setauket. }\end{array}$ & $\begin{array}{r}10-25-78 \\
4-12-79 \\
8-23-79 \\
11-8-79 \\
7-15-80 \\
9-15-80\end{array}$ & $\begin{array}{l}.27 \\
.37 \\
.14 \\
.14 \\
.35 \\
.29\end{array}$ \\
\hline 01304070 & $\begin{array}{l}\text { Unnamed Tributary to } \\
\text { Port Jefferson Harbor } \\
\text { at Port Jefferson. }\end{array}$ & $\begin{array}{l}\text { Lat } 40^{\circ} 56^{\prime} 41^{\prime \prime}, \text { long } 73^{\circ} 04^{\prime} 18^{\prime \prime} \text {, } \\
\text { Suffolk County, at culvert } \\
\text { on Barnum Ave., at Port } \\
\text { Jefferson. }\end{array}$ & $\begin{array}{r}10-25-78 \\
4-12-79 \\
11-8-79 \\
7-15-80 \\
9-15-80\end{array}$ & $\begin{array}{l}.57 \\
1.0 \\
.41 \\
.77 \\
.47\end{array}$ \\
\hline 01304990 & $\begin{array}{l}\text { Carmans River at } \\
\text { Middle Island. }\end{array}$ & $\begin{array}{l}\text { Lat } 40^{\circ} 51^{\prime} 47^{\prime \prime}, \text { long } 72^{\circ} 56^{\prime} 35^{\prime \prime}, \\
\text { Suffolk County, at culvert } \\
\text { on East Bartlett Road, } 0.75 \\
\text { mile south of Middle Island, } \\
\text { and } 3.0 \text { miles upstream from } \\
\text { gaging station at Yaphank. }\end{array}$ & $\begin{array}{r}8-31-78 \\
10-26-78 \\
5-17-79 \\
10-18-79 \\
6-18-80 \\
9-5-80\end{array}$ & $\begin{array}{l}3.0 \\
2.4 \\
7.0 \\
4.1 \\
3.7 \\
1.4\end{array}$ \\
\hline 01304995 & $\begin{array}{l}\text { Carmans River near } \\
\text { Yaphank. }\end{array}$ & $\begin{array}{l}\text { Lat } 40^{\circ} 50^{\prime} 29^{\prime \prime}, \text { long } 72^{\circ} 56^{\prime} 13^{\prime \prime} \text {, } \\
\text { Suffolk County, } 25 \mathrm{ft} \text { down- } \\
\text { stream from Mill Road, } 1.2 \\
\text { miles northwest of Yaphank, } \\
\text { and } 1.9 \text { miles upstream from } \\
\text { gaging station at Yaphank. }\end{array}$ & $\begin{array}{r}8-31-78 \\
10-16-78 \\
5-17-79 \\
10-18-79 \\
6-18-80 \\
9-5-80\end{array}$ & $\begin{array}{r}5.8 \\
11.8 \\
26.6 \\
16.0 \\
16.3 \\
10.3\end{array}$ \\
\hline 01304998 & $\begin{array}{l}\text { Carmans River, below } \\
\text { Lower Lake, at } \\
\text { Yaphank. }\end{array}$ & $\begin{array}{l}\text { Lat } 40^{\circ} 50^{\prime} 07^{\prime \prime}, \text { long } 72^{\circ} 55^{\prime} 01^{\prime \prime}, \\
\text { Suffolk County, at culvert } \\
\text { on Yaphank Ave., at Yaphank, } \\
\text { and } 0.7 \text { mile upstream from } \\
\text { gaging station at Yaphank. }\end{array}$ & $\begin{array}{r}8-31-78 \\
10-16-78 \\
5-17-79 \\
10-18-79 \\
6-18-80 \\
9-5-80 \\
\end{array}$ & $\begin{array}{l}13.4 \\
20.5 \\
36.5 \\
31.4 \\
28.0 \\
15.8 \\
\end{array}$ \\
\hline
\end{tabular}


addition, subsurface ground water discharges directly to Long Island Sound along the north shore. This is apparent where the potentiometric heads in the Magothy aquifer are greater than or equal to the potentiometric heads in the upper glacial aquifer.

\section{Upper Glacial Aquifer}

The upper glacial aquifer consists of the saturated material of the Pleistocene and Holocene deposits. It contributes more than half the public water supply for the northern part of the Town of Brookhaven. The upper limit of the saturated zone is known as the water table. The altitude of the water table fluctuates seasonally and is influenced by several factors such as water-transmitting properties of the aquifer, location of discharge points, such as streams or pumping wells, and quantity of precipitation.

In 1980, water-level measurements in 50 observation we $11 \mathrm{~s}$ were used to prepare a water-table map of the northern part of the Town of Brookhaven (p1 4). The water table has a maximum altitude of 72 feet above sea level in the central part of the area and decreases to sea level along the north shore. Along the southern boundary of the area, the water table ranges in altitude from 52 feet in the west to about 33 feet in the east (p1. 4). The lower altitude in the east results from the discharge of ground water into the Carmans River basin.

In the central part of the area, where the so-called Smithtown clay is present, wells screened above the clay show significantly higher water levels than those screened below it. An example is wel1 S41050 and we11 S40331 in Selden (p1. 1). In 1980, the water leve1 in we11 S41050 was $72.1 \mathrm{ft}$ above sea level and in we11 S40331, $62 \mathrm{ft}$ above sea level. The 10-foot difference is due to the perching effect of the clay, which in this area is $90 \mathrm{ft}$ thick. The extent and thickness of this unit is an important factor in determining the amount and rate of recharge to the underlying Magothy aquifer. This clay retards the vertical component of ground-water movement, thereby reducing the rate of recharge to the underlying sands and gravels.

Synoptic water-leve 1 measurements made in the northern part of the Town of Brookhaven from $1977-80$ as we 11 as long-term records from observation we11s indicate that the water table generally rises during the cooler months (October-April) and declines in the warmer months (May-September). Maximum seasonal fluctuations of water levels in the area are generally less than 3 $\mathrm{ft}$, except along the ground-water divide ( 1.4$)$, where fluctuations may be as great as $5 \mathrm{ft}$. Water levels in wells along Long Island Sound are subject to tidal fluctuations.

The U.S. Geological Survey has monitored several observation wells in the area since the early 1950's. Figure 9 depicts 1960-79 hydrographs for four of the we1ls.

The hydraulic characteristics of the upper glacial aquifer on Long Island were summarized by McClymonds and Franke (1972), who estimated the average hydraulic conductivity and transmissivity of the aquifer in the area from specific-capacity data of wells. They used the following equation to determine average hydraulic conductivity of the aquifer: 

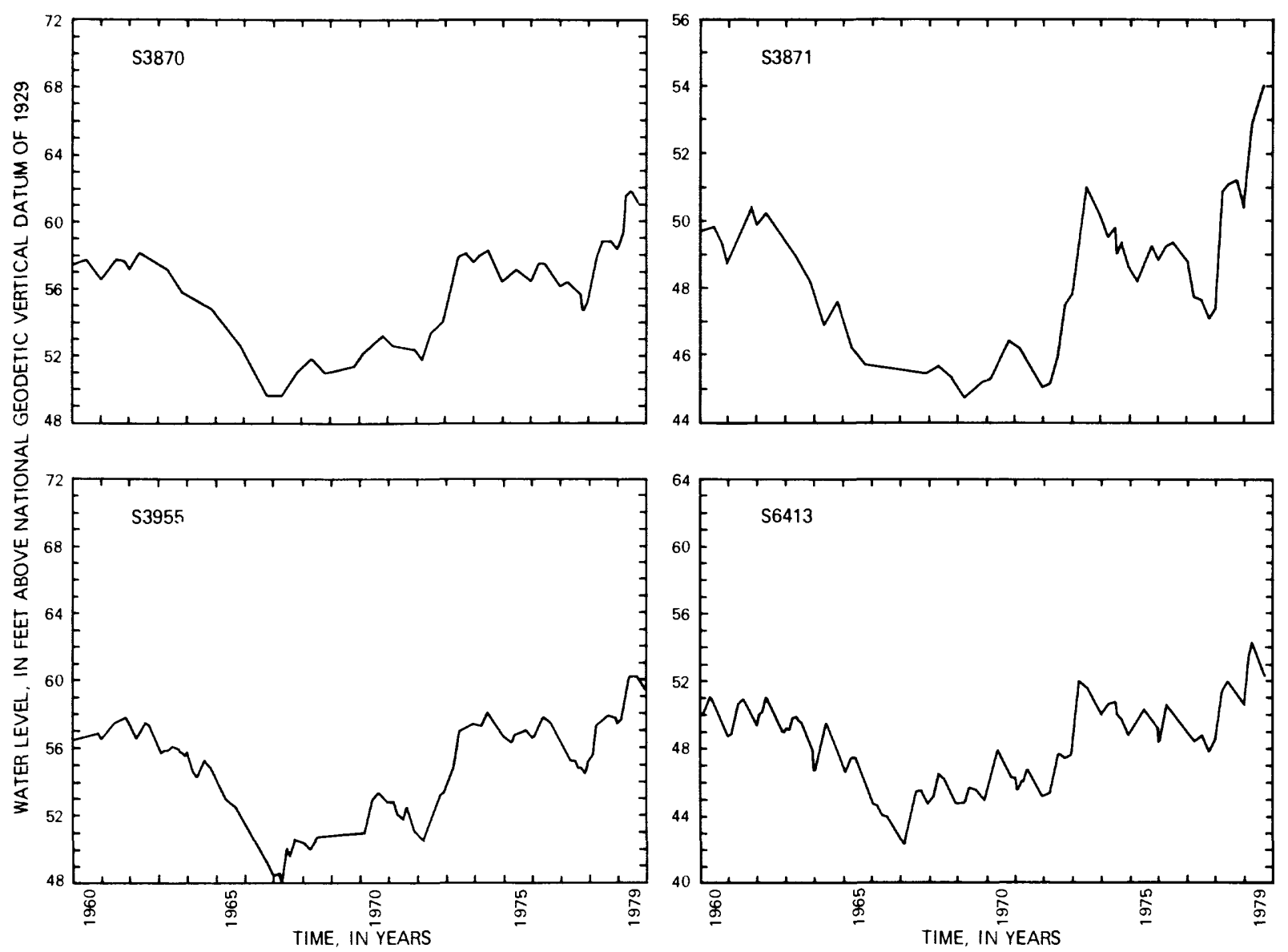

Figure 9.--Twenty-year hydrograph for wells S3870, S3871, S3955, and 56413. (Locations are given in pl. 1.)

$$
\overline{\mathrm{K}}=114.6 \mathrm{~W}(\mathrm{u}) \frac{\mathrm{Q}}{\mathrm{sL}}
$$

where: $\overline{\mathrm{K}}=$ average hydraulic conductivity of the materials opposite the well screen, in gallons per day per square foot;

$W(u)=$ well function of $u$, where $u=1.87 \mathrm{r}^{2} \mathrm{~s} / \mathrm{Tt}$;

$Q=$ discharge of pumping well, in gallons per minute,

$\mathrm{s}=\mathrm{drawdown}$ in pumping we11, in feet,

$\mathrm{L}=$ length of well screen, in feet,

$\mathbf{r}=$ distance from pumping well to point of observation, in feet,

$S=$ coefficient of storage, expressed as a decimal fraction, and

$t=$ time since pumping started, in days. 
McClymonds and Franke (1972) further simplified equation (2) by assuming the approximate value of $114.6 \mathrm{~W}(\mathrm{u})$ to be 2,000 . Therefore, equation (2) is:

$$
\overline{\mathrm{K}}=2,000 \frac{\mathrm{Q}}{\mathrm{sL}}
$$

where: $\frac{Q}{\text { SL }}=$ specific capacity of the well per foot of well screen.

Many simplifying assumptions were made in deriving these equations; one was that the length of the well screen is equal to the thickness of aquifer material that contributes all the water to the we11. In a water-table aquifer, such as the upper glacial aquifer, however, this is rarely the case. The storage coefficient for the upper glacial aquifer ranges from 0.20 to 0.25 , with a general value of 0.22 . Substituting this value into the calculation of the well function, $W(u)$, gives an approximate value of 1500 . However, this method can be used to estimate average hydraulic conductivity and transmissivity. Other assumptions used in this method are discussed in detail by Bredehoeft (1963).

From this analysis, the estimated average hydraulic conductivity of the upper glacial aquifer in the area generally ranges from less than 130 to 270 $\mathrm{ft} / \mathrm{d}$, or 1,000 to $2,000(\mathrm{gal} / \mathrm{d}) / \mathrm{ft}^{2}$. A more general range would be 100 to 300 $\mathrm{ft} / \mathrm{d}$. The latter range takes into account the fact that the technique used, and the assumption that $114.6 \mathrm{~W}(\mathrm{u})$ is approximately equal to 2,000, do not yield precise values of hydraulic conductivity.

McClymonds and Franke (1972) also calculated the transmissivity of the aquifer in the study area. Using a range of saturated thickness from $100 \mathrm{ft}$ to $200 \mathrm{ft}$, they estimated that transmissivity would range from 26,700 to $53,500 \mathrm{ft}^{2} / \mathrm{d}(200,000$ to $400,000(\mathrm{gal} / \mathrm{d}) / \mathrm{ft})$. The higher end of this range is conservative because the Pleistocene channel deposits extend to depths greater than $600 \mathrm{ft}$ below sea level. From the information shown in plates 2 and 4, a more accurate upper limit for saturated thickness would be $350 \mathrm{ft}$, and the maximum transmissivity would be increased to about $105,000 \mathrm{ft}^{2} / \mathrm{d}$.

\section{Magothy Aquifer}

The Magothy aquifer consists of the Cretaceous deposits of the Magothy Formation and Matawan Group, undifferentiated. The difference in sediment size and distribution in this aquifer is the major criterion for differentiating it from the overlying upper glacial aquifer. The two aquifers are hydraulically connected except in some areas to the south, where they are separated by marine clay. The Magothy aquifer contributes about a third of the public water supply in the study area.

A potentiometric-surface map of the Magothy aquifer was prepared from water-leve 1 measurements collected from 18 wells in April 1980 (p1. 5). The potentiometric surface represents the static head that is indicated by the level to which water would rise in a tightly cased well screened in the 
aquifer. The potentiometric surface of the Magothy aquifer has a maximum altitude of $61 \mathrm{ft}$ above sea level in the central part of the study area and decreases to less than $10 \mathrm{ft}$ above sea level along the north shore. To the east, data are lacking, and the contours shown in plate 5 are speculative.

Hydraulic conductivity and transmissivity of the Magothy aquifer in the area were calculated by McClymonds and Franke (1972) from specific-capacity values, as discussed previously. Average hydraulic conductivity of the Magothy aquifer is estimated to range from 50 to $70 \mathrm{ft} / \mathrm{d}$, or 400 to 500 $(\mathrm{ga} 1 / \mathrm{d}) / \mathrm{ft}^{2}$.

The transmissivity of the Magothy aquifer was calculated by McClymonds and Franke (1972) to range from about 13,400 to $40,000 \mathrm{ft}^{2} / \mathrm{d}(100,000$ to $300,000(\mathrm{gal} / \mathrm{d}) / \mathrm{ft})$. The lower limit may be too high because the saturated thickness of the aquifer in the channeled areas is probably less than earlier studies indicated.

\section{Lloyd Aquifer}

The Lloyd aquifer is composed of the Lloyd Sand Member of the Raritan Formation. One well (S31734) penetrates the aquifer in the area; the water level measured in March 1980 was $43 \mathrm{ft}$ above sea level. The Lloyd aquifer is not used for water supply in the area at present.

Hydraulic conductivity and transmissivity of the aquifer in the study area were estimated by McClymonds and Franke (1972) to be $43 \mathrm{ft} / \mathrm{d}$ or 320 $(\mathrm{gal} / \mathrm{d}) / \mathrm{ft}^{2}$, and transmissivity to be $10,000 \mathrm{ft}^{2} / \mathrm{d}$ or $75,000(\mathrm{gal} / \mathrm{d}) / \mathrm{ft}$.

\section{Water Quality}

The chemical quality of water influences the purposes for which the water may be used--such as drinking, agriculture, or industry. The chemical quality of the water is determined by the type and solubility of earth materials with which the water comes in contact, the duration of contact, the chemical quality of precipitation, the temperature, the pressure, and the presence of surface-derived substances such as domestic wastes, fertilizers, and industrial discharges.

The water in the northern part of the Town of Brookhaven is generally acceptable for drinking and most other uses. However, some constituents, for example, iron, chloride, and nitrate-nitrogen, occur locally in concentrations exceeding Federal and State drinking-water standards.

Chemical analyses from 27 observation we1ls screened in the upper glacial aquifer, 34 public-supply wells screened in upper glacial aquifer, and 27 public-supply wells screened in the Magothy aquifer in the area are given in Koszalka (1980). Statistical data, on the chemical constituents and properties of water samples from these wells, collected and analyzed in 1978, are given in tables 6 and 7 . Table 6 summarizes the observation wells; table 7 the public-supply wells. Analyses from wells screened in the upper glacial aquifer and downgradient from, or within 200 feet of, secondary sewagetreatment plants are given in the second part of table 6 ; these values probably do not reflect the general ground-water quality. Analyses of samples from wells not affected by sewage indicate the water to be of good quality. 
Table 6.--Chemical analyses of ground water from observation wells screened in the upper glacial aquifer in the northern part of the

Town of Brookhaven, 1978.

[A11 concentrations are in milligrams per liter]

\begin{tabular}{|c|c|c|c|c|c|c|}
\hline \multirow[b]{2}{*}{$\begin{array}{l}\text { Constituent } \\
\text { or property }\end{array}$} & \multirow{2}{*}{$\begin{array}{l}\text { Number } \\
\text { of } \\
\text { samples }\end{array}$} & \multicolumn{5}{|c|}{ Concentration or value } \\
\hline & & Minimum & $\begin{array}{c}\text { l0th } \\
\text { percentile }\end{array}$ & Median & $\begin{array}{c}90 \mathrm{th} \\
\text { percentile }\end{array}$ & Maximum \\
\hline & A. We $11 \mathrm{~s}$ & distant & from sewage- & treatmen & t plants & \\
\hline $\begin{array}{l}\text { Specific con- } \\
\text { ductance }(\mu \mathrm{mho} / \\
\left.\text { cm at } 25^{\circ} \mathrm{C}\right)\end{array}$ & 18 & 40 & 60 & 176.5 & 320 & 500 \\
\hline $\mathrm{pH}$ & 18 & 4.2 & 5.0 & 5.9 & 6.3 & 6.6 \\
\hline Alkalinity & 18 & 2 & 5 & 16 & 35 & 44 \\
\hline Nitrite $\left(\mathrm{NO}_{2}\right)$ & 17 & .00 & .00 & .00 & .01 & .01 \\
\hline Nitrate $\left(\mathrm{NO}_{3}\right)$ & 17 & .00 & .07 & 1.7 & 5.9 & 8.7 \\
\hline Total hardness & & & & & & \\
\hline$\left(\right.$ as $\left.\mathrm{CaCO}_{3}\right)$ & 18 & 9 & 15 & 44 & 81 & 140 \\
\hline Calcium ( $\mathrm{Ca})$ & 18 & 2.0 & 2.7 & 12 & 21 & 39 \\
\hline Magnesium (Mg) & 18 & 1.0 & 1.2 & 3.75 & 7.8 & 10.0 \\
\hline Sodium (Na) & 18 & 4.0 & 4.3 & 13.5 & 34 & 55 \\
\hline Potassium (K) & 18 & .6 & .9 & 1.4 & 2.9 & 3.7 \\
\hline Chloride (C1) & 18 & 5.3 & 6.0 & 17.5 & 46 & 64 \\
\hline Sulfate $\left(\mathrm{SO}_{4}\right)$ & 18 & 2.0 & 2.7 & 14 & 39 & 100 \\
\hline Iron (Fe) & 18 & .18 & .30 & 1.3 & 5.4 & 40.0 \\
\hline Manganese $(M n)$ & 18 & 0.0 & 0.0 & .04 & .29 & .99 \\
\hline Dissolved solids & 18 & 34 & 45 & 104 & 193 & 227 \\
\hline $\begin{array}{l}\text { Specific con- } \\
\text { ductance ( } \mu \mathrm{mho} / \\
\mathrm{cm} \text { at } 25^{\circ} \mathrm{C} \text { ) }\end{array}$ & 18 & 105 & 160 & 275 & 460 & 1,300 \\
\hline $\mathrm{pH}$ & 18 & 5.1 & 5.2 & 6.0 & 6.7 & 6.9 \\
\hline Nitrite $\left(\mathrm{NO}_{2}\right)$ & 19 & .00 & .00 & .00 & .01 & .14 \\
\hline Nitrate $\left(\mathrm{NO}_{3}\right)$ & 19 & .00 & .00 & 1.3 & 13 & 20 \\
\hline Total hardness & & & & & & \\
\hline$\left(\right.$ as $\left.\mathrm{CaCO}_{3}\right)$ & 14 & 13 & 13 & 45 & 62 & 82 \\
\hline Calcium ( $\mathrm{Ca}$ ) & 14 & 3.9 & 3.9 & 13 & 17 & 19 \\
\hline Magnesium (Mg) & 14 & .8 & .8 & 3.1 & 6.8 & 8.3 \\
\hline Sodium (Na) & 19 & 13 & 15 & 26 & 65 & 240 \\
\hline Potassium (K) & 19 & 1.9 & 1.9 & 5.0 & 11 & 59 \\
\hline Chloride (C1) & 19 & 6.5 & 13 & 26 & 58 & 290 \\
\hline Sulfate $\left(\mathrm{SO}_{4}\right)$ & 19 & 2.2 & 5.1 & 21 & 34 & 43 \\
\hline Iron (Fe) & 19 & .10 & .10 & .62 & 5.0 & 8.4 \\
\hline Manganese (Mn) & 19 & .03 & .03 & .68 & 2.60 & 8.5 \\
\hline Dissolved solids & 14 & 85 & 85 & 194 & 278 & 682 \\
\hline
\end{tabular}

Analyses by U.S. Geological Survey Laboratories in Albany, N.Y., and Atlanta, $\mathrm{Ga}$. 
Table 7.--Chemical analyses of ground water from public-supply wells in the northern part of the Town of Brookhaven, 1978.

[A11 concentrations are in milligrams per liter]

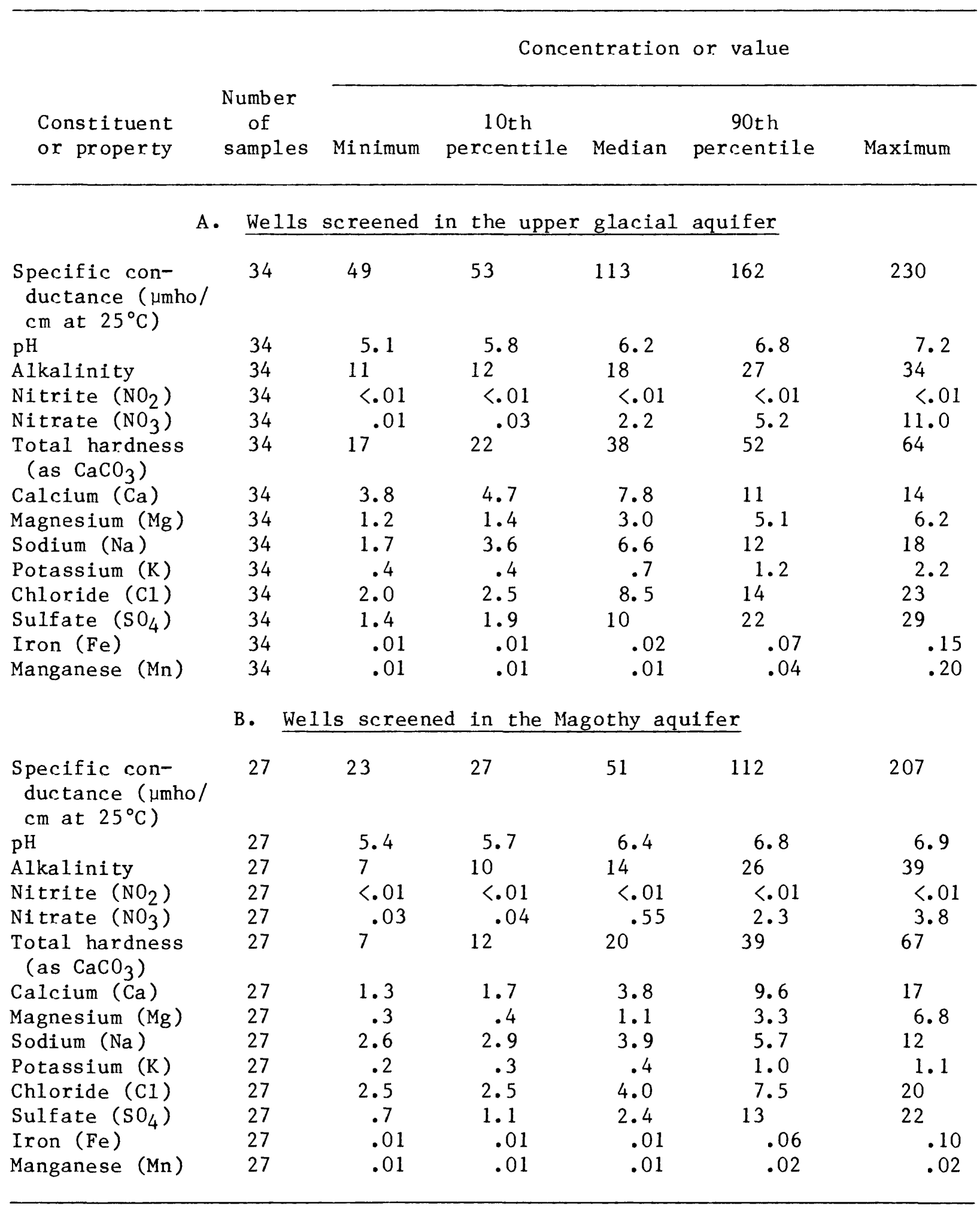


Only one we11, S31734 (p1. 1), penetrates the Lloyd aquifer in the study area. A chemical analysis of water from this well in 1972 indicated the water to be of suitable quality for drinking. Specific conductance was $87 \mu \mathrm{mho} / \mathrm{cm}$ at $25^{\circ} \mathrm{C}$, the $\mathrm{pH}$ was 10.3 , alkalinity (as $\mathrm{CaCO}_{3}$ ) was $22 \mathrm{mg} / \mathrm{L}$, and hardness (as $\mathrm{CaCO}_{3}$ ) was $13 \mathrm{mg} / \mathrm{L}$. Dissolved iron concentration was $0.62 \mathrm{mg} / \mathrm{L}$, and dissolved chloride concentration was $5.0 \mathrm{mg} / \mathrm{L}$. Total dissolved solids was $41 \mathrm{mg} / \mathrm{L}$.

Koszalka (1980, table 7) presented chemical analyses of water from seven stream sites. They indicate that fresh surface water in the study area is suitable for most uses.

\section{SUMMARY AND CONCLUSIONS}

Ground water is the sole source of water supply in the northern part of the Town of Brookhaven. The availability of this water supply depends upon the hydraulic characteristics of the aquifers and the chemical quality of the ground water they contain.

The northern part of the Town of Brookhaven consists of Paleozoic bedrock overlain by Upper Cretaceous, Pleistocene, and Holocene deposits. The surficial material consists of morainal and outwash deposits of Wisconsin age in association with recent beach and marsh deposits.

Precipitation is the only source of ground water for the area. About 21.5 inches per year reaches the ground-water reservoir from the average annual precipitation of 44.4 inches. Overland runoff is estimated to be about 0.5 inches per year, and average annual evapotranspiration is estimated to be 22.4 inches per year.

The three aquifers that underlie the northern part of the Town of Brookhaven are capable of producing more than the current $23.2 \mathrm{Mgal} / \mathrm{d}$ withdrawal. Both the upper glacial and Magothy aquifers are the most readily available source for supplying additional needs. At present, it is unlikely that the Lloyd aquifer would be needed as an additional source of ground water in the area.

Hydraulic conductivity and transmissivity of the aquifers were estimated from specific-capacity tests. Average hydraulic conductivity ranges from 100 to $300 \mathrm{ft} / \mathrm{d}$ in the upper glacial aquifer and from 50 to $70 \mathrm{ft} / \mathrm{d}$ in the Magothy aquifer. Transmissivity ranges from 25,000 to $105,000 \mathrm{ft}^{2} / \mathrm{d}$ in the upper glacial aquifer and from 13,000 to $41,000 \mathrm{ft}^{2} / \mathrm{d}$ in the Magothy aquifer. Only sparse data on the Lloyd aquifer are available; average hydraulic conductivity and transmissivity are estimated to be $40 \mathrm{ft} / \mathrm{d}$ and $10,000 \mathrm{ft}^{2} / \mathrm{d}$, respectively.

Ground water in the northern part of the Town of Brookhaven is generally acceptable for drinking and other uses. However, some constituents, particularly iron, chloride, and nitrate-nitrogen, occur locally in concentrations exceeding Federal and State drinking-water standards. Water from observation wells near or downgradient from small secondary sewage-treatment plants indicates possible point-source pollution in the upper glacial aquifer. Fresh surface water in the area is of suitable chemical quality for most uses. 


\section{REFERENCES CITED}

Bart, Jeffrey, and others, 1976, Preliminary hydrologic investigations of the South Fork of Long Island: Princeton, N.J., Princeton University Water Resources Program WRP 76-1, p. A1-G36.

Bredehoeft, J. D., 1963, Hydrogeology of the Lower Humboldt River Basin, Nevada: Nevada University, Desert Research Institute, Technical Report $3,50 \mathrm{p}$.

Cohen, Philip, Franke, O. L., and McClymonds, N. E., 1969, Hydrologic effects of the 1962-66 drought on Long Island, New York: U.S. Geological Survey Water-Supply Paper 1879F, p. F1-F18, 10 figs.

Fuller, M. L., 1914, The geology of Long Island, New York: U.S. Geological Survey Professional Paper 82, 231 p.

Holzmacher, McLendon, and Murrel1, 1968, Comprehensive public water supply study, Suffolk County, New York: Melville, N.Y., Holzmacher, McLendon and Murre11, CPWS $-24,3$ v.

Jensen, H. M., and Soren, Julian, 1974, Hydrogeology of Suffolk County, Long Island, New York: U.S. Geological Survey Hydrologic Investigation Atlas HA-501, 2 sheets.

Kimme1, G. E., 1971, The water table on Long Island, New York, in March 1970: Long Island Water Resources Bulletin 2, 8 p., 2 figs., 3 pl.

Koch, Ellis, and Koszalka, E. J., 1973, Potentiometric surface of the lower part of the Magothy aquifer in March 1972, Long Island, New York: U.S. Geological Survey open-file report, $1 \mathrm{p} 1$.

Koszalka, E. J., 1975, The water table on Long Island, New York, in March 1974: Long Island Water Resources Bulletin 5, 7 p., 1 fig., 3 pl.

1980, Hydrogeologic data from the northern part of the Town of Brookhaven, Suffolk County, New York: Long Island Water Resources Bu11. 15, $80 \mathrm{p}$.

Koszalka, E. J., and Koch, Ellis, 1974, Water table on Long Island, New York, March 1971: U.S. Geological Survey open-file report, 1 map.

Long Island Lighting Company, 1978, Population survey: current population estimates for Nassau and Suffolk Counties, 48 p.

Lubke, E. R., 1964, Hydrogeology of the Huntington-Smithtown area, Suffolk County, New York: U.S. Geological Survey Water-Supply Paper 1669-D, 68 p., 12 figs., 6 pl.

McClymonds, N. E., and Franke, O. L., 1972, Water-transmitting properties of aquifers on Long Island, New York: U.S. Geological Survey Professional Paper 627-E, 24 p., 22 figs., 3 p1. 


\section{REFERENCES CITED (continued)}

Miller, J. F., and Frederick, R. H., 1969, The precipitation regime of Long Island, New York: U.S. Geological Survey Professional Paper 627-A, 21 p.

Nakao, J. H., and Erlichman, F. R. 1978, The water table on Long Island, New York, in March 1975: U.S. Geological Survey Open-File Report 78-569, 10 p., 1 pl.

Prince, K. R., 1976, The potentiometric surface of the Magothy aquifer on Long Island, New York, in March 1975: U.S. Geological Survey Open-File Report $76-536,12 \mathrm{p} ., 1 \mathrm{pl}$.

Suter, Russell, de Laguna, Wallace, and Perlmutter, N. M., 1949, Mapping of geologic formations and aquifers of Long Island, New York: New York State Water Power and Control Commission Bulletin GW-18, 212 p., pp. 185-311.

Thornthwaite, C. W., and Mather, J. R., 1957, Instructions and tables for computing potential evapotranspiration and the water balance: Drexel Institute of Technology, Publications in Climatology, v. x, no. 3, $311 \mathrm{p}$.

U.S. Geological Survey, Water resources data for New York, Volume 2--Long Island: U.S. Geological Survey Water-data report (issued annually).

Vaupe1, D. E., Prince, K. R., Koehler, A. J., and Runco, Mario, 1977, Potentiometric surfaces of the upper glacial and Magothy aquifers and selected streamflow statistics, 1943-1972, on Long Island, New York: U.S. Geological Survey Open-File Report 77-528, 23 p. 


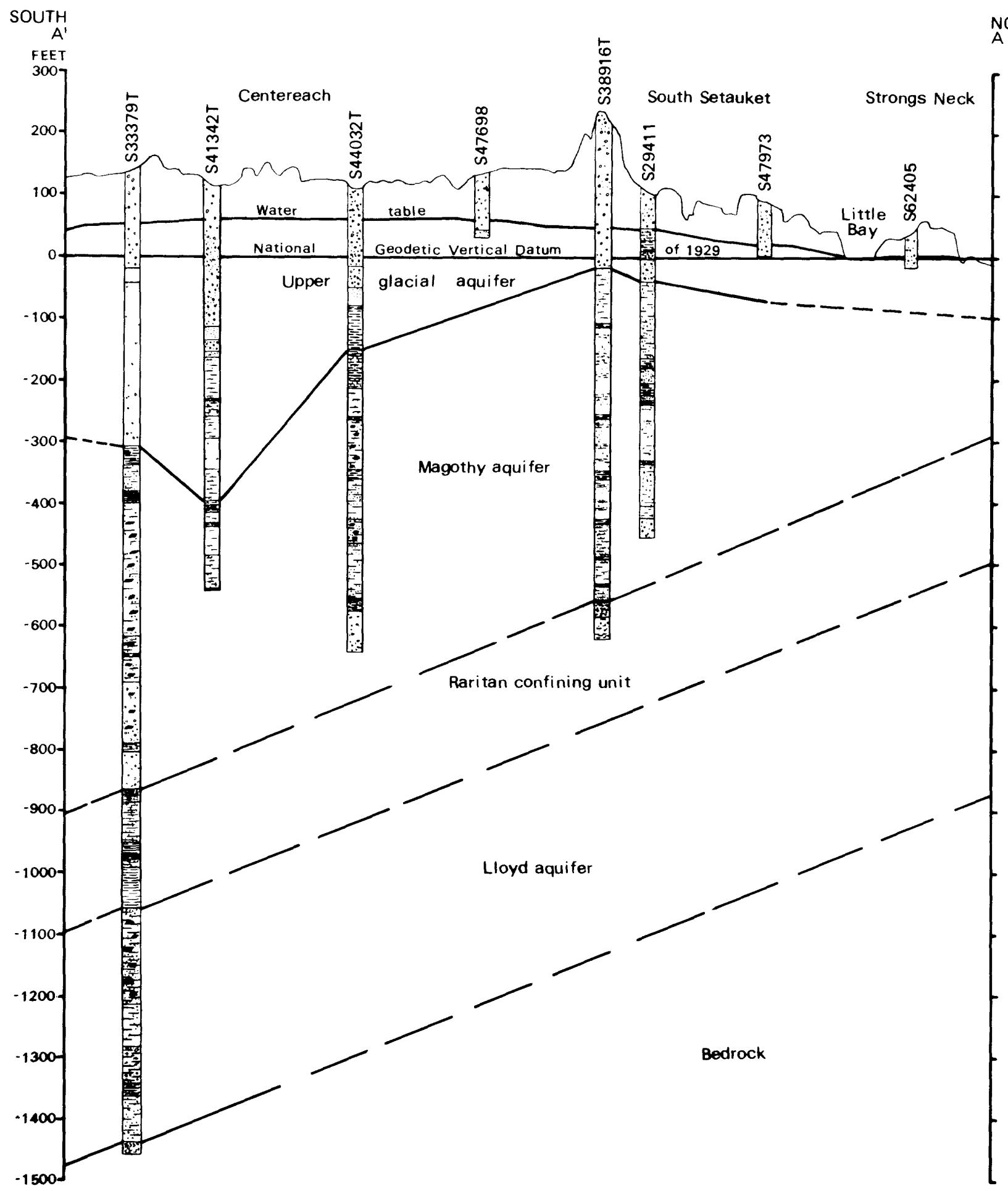

Figure 10.--Hydrogeologic section $A-A^{\prime}$, northern part of the Town of Brookhaven, Suffolk County, N.Y. (Location is shown in pl. 1). 


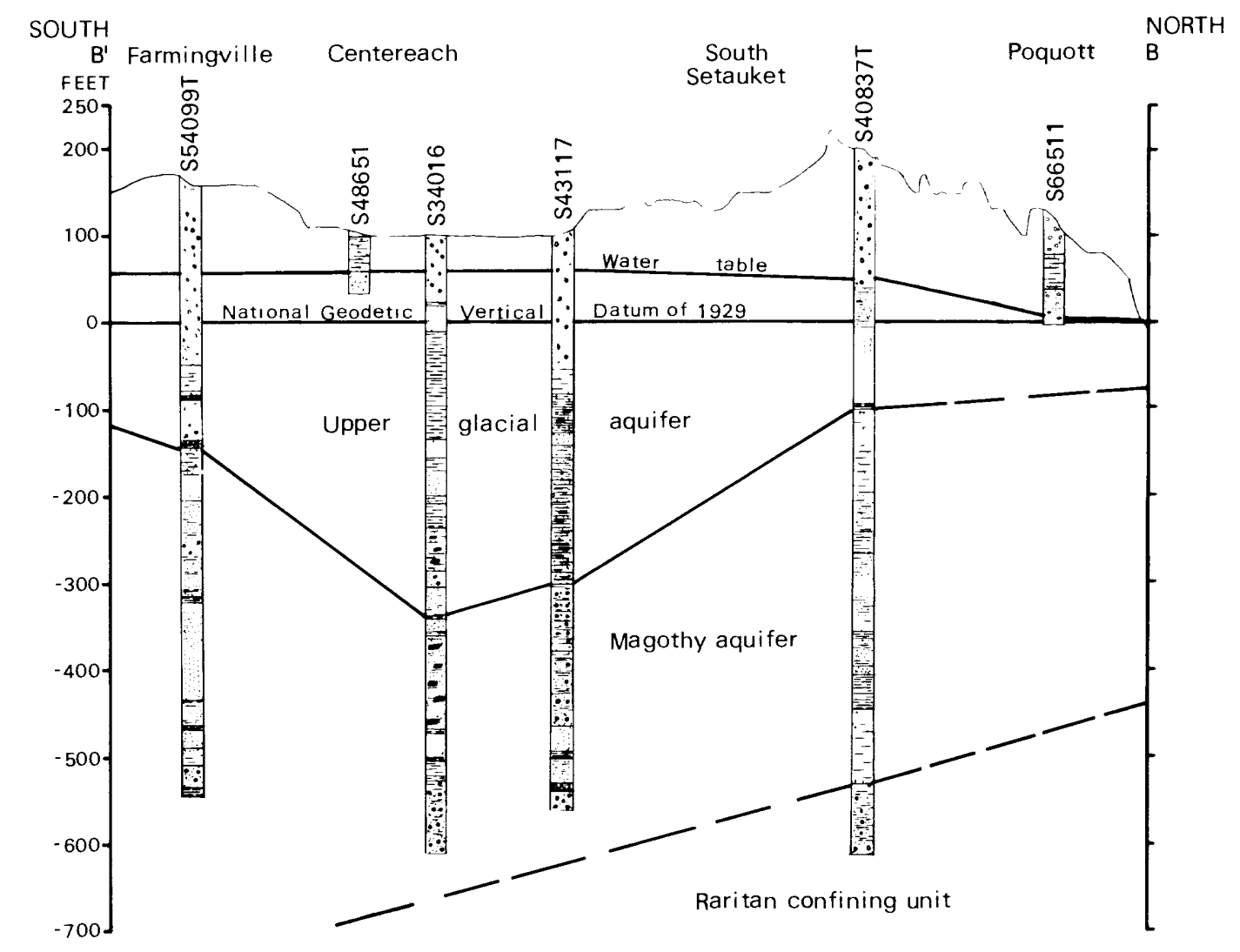

Figure 10 (continued).--Hydrogeologic section $B-B^{\prime}$, northern part of the Town of Brookhaven, Suffolk County, N.Y. (Location is shown in pl. 1). 


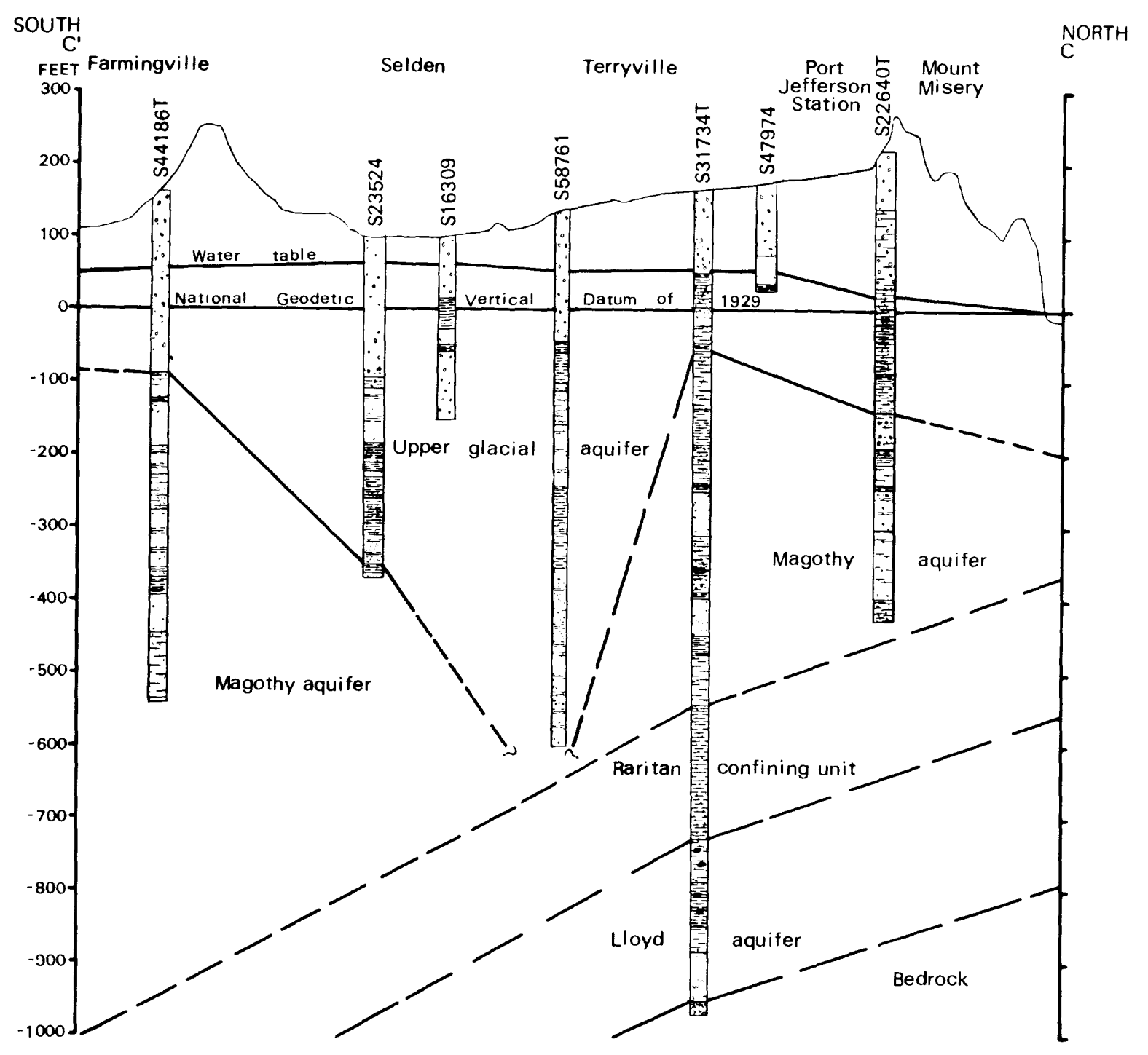

Figure 10 (continued).--Hydrogeologic section $C-C^{\prime}$, northern part of the Town of Brookhaven, Suffolk County, N.Y. (Location is shown in pl. 1). 


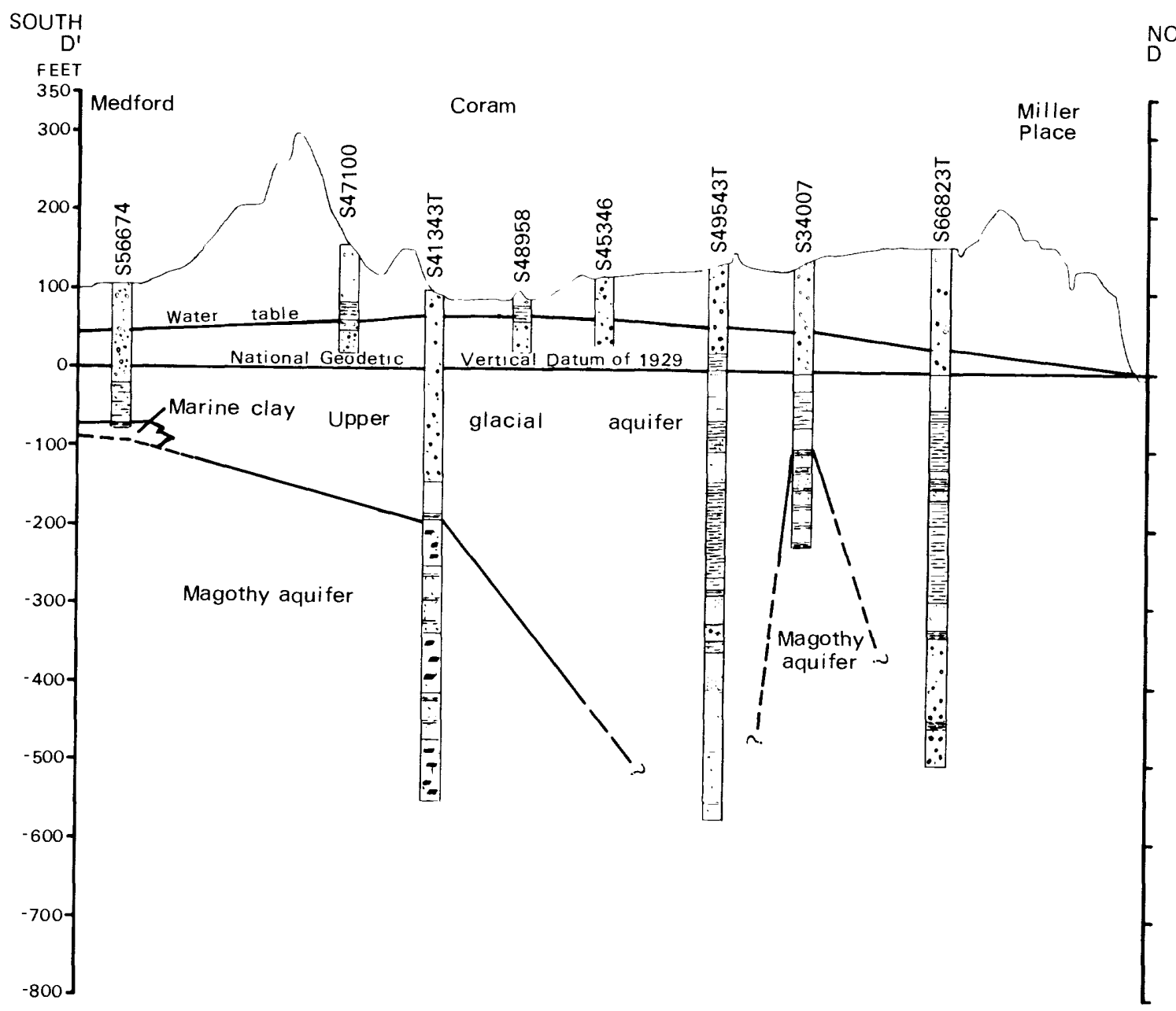

Figure 10 (continued).--Hydrogeologic section $D-D^{\prime}$, northern part of the Town of Brookhaven, Suffolk County, N.Y. (Location is shown in pl. 1). 


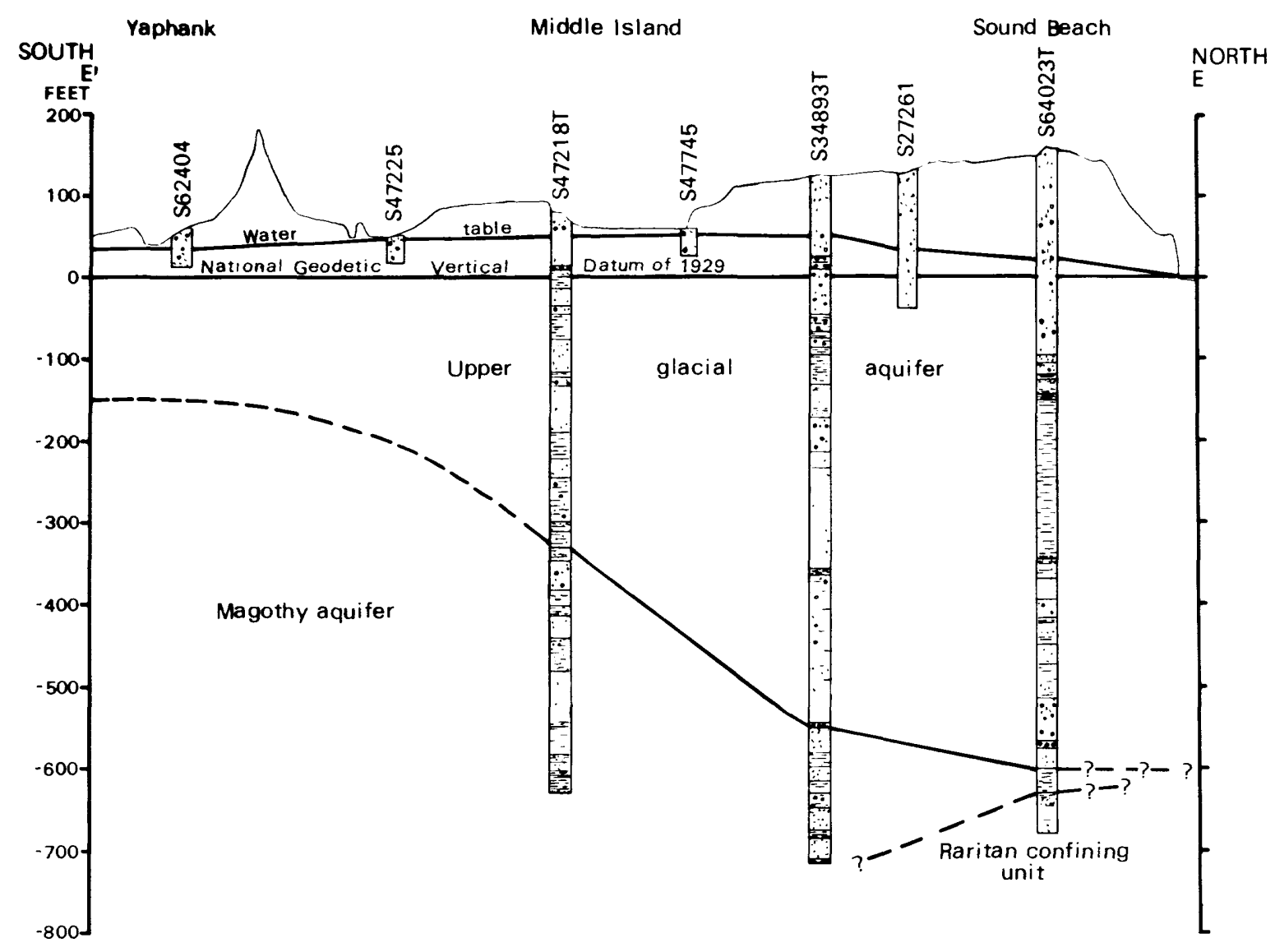

Figure 10 (continued).--Hydrogeologic section $E-E^{\prime}$, northern part of the Town of Brookhaven, Suffolk County, N.Y. (Location is shown in pl. 1). 


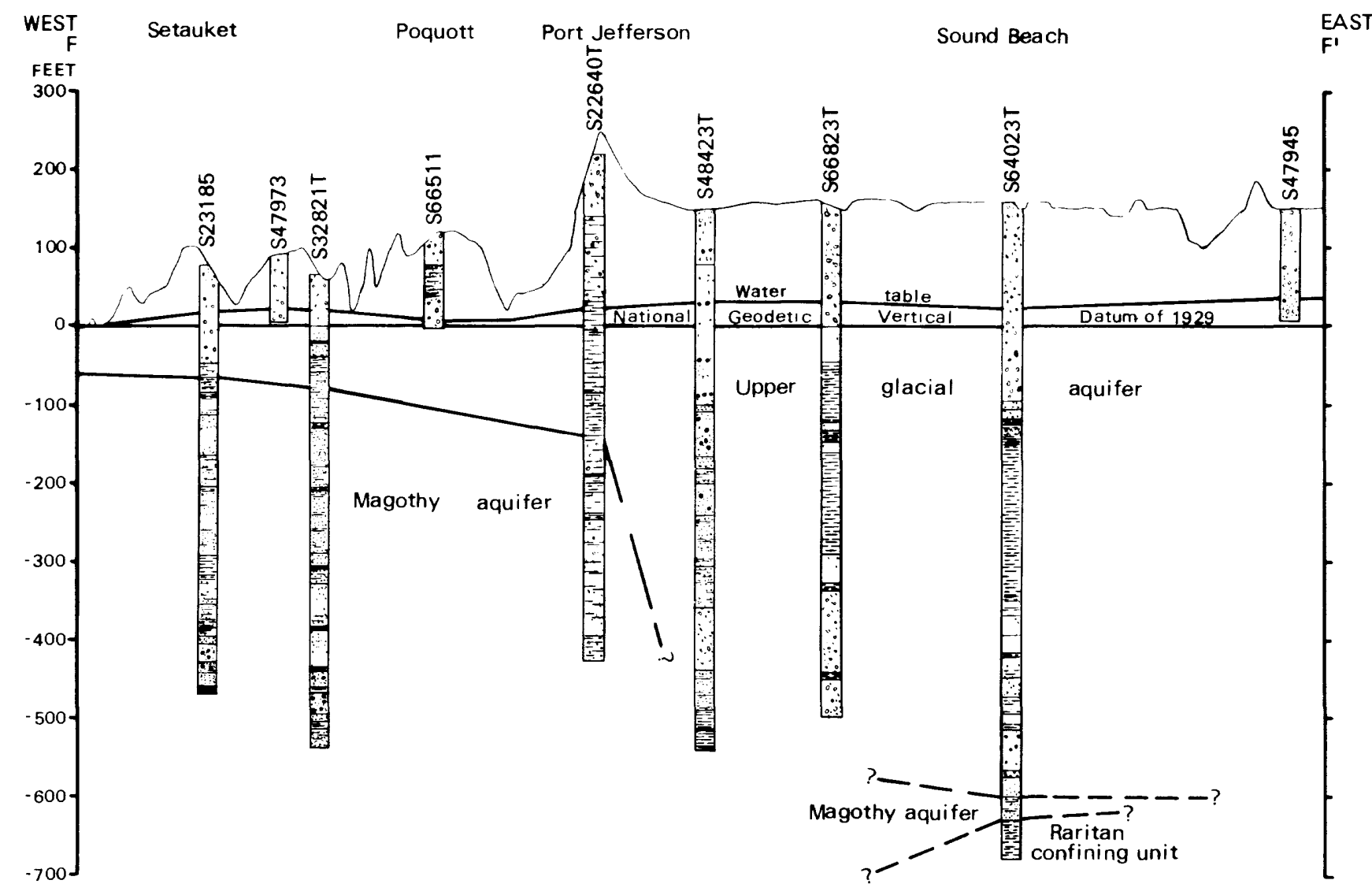

Figure 10 (continued).--Hydrogeologic section $F-F^{\prime}$, northern part of the Town of Brookhaven, Suffolk County, N.Y. (Location is shown in pl. 1). 


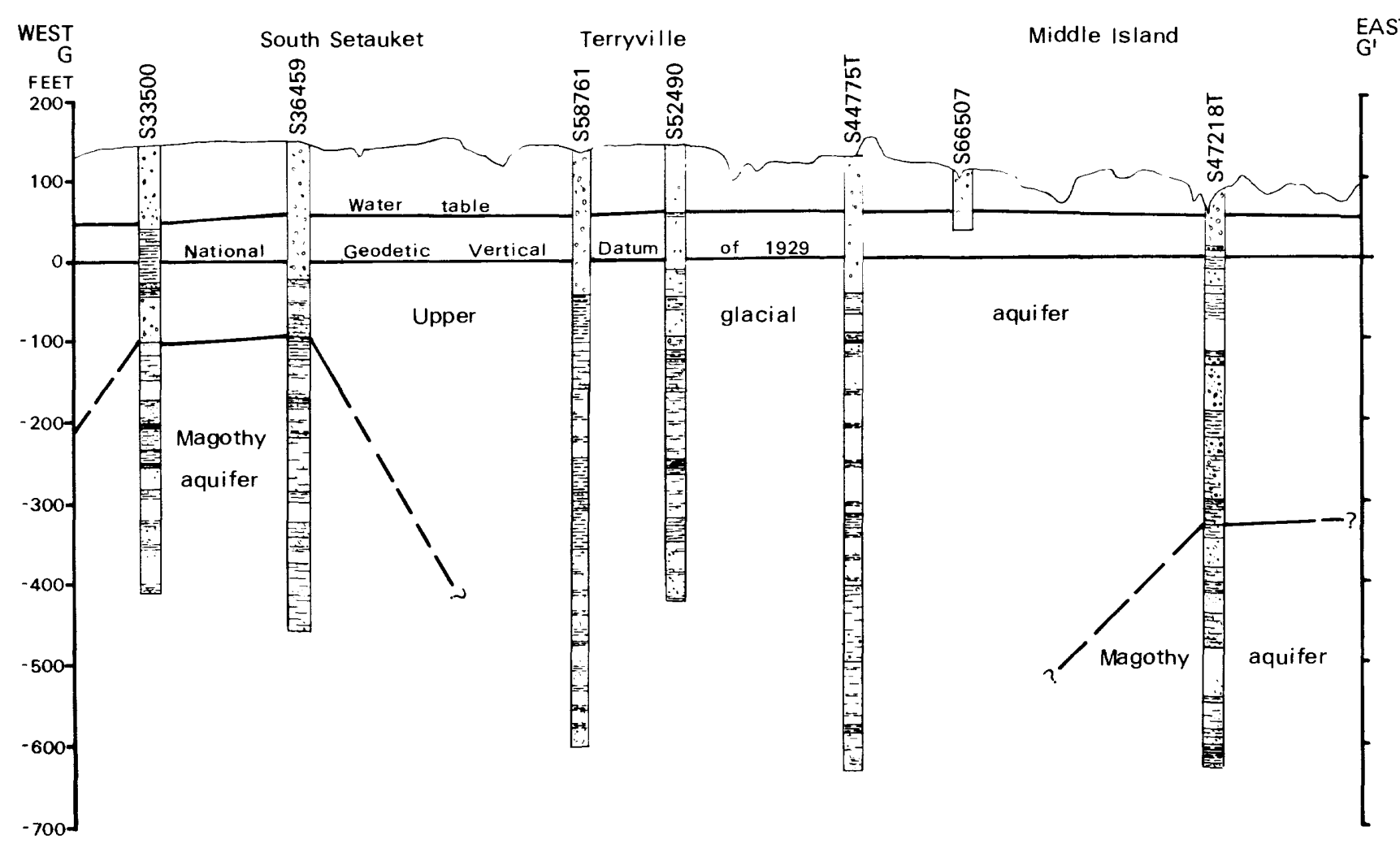

Figure 10 (continued).--Hydrogeologic section $G-G^{\prime}$, northern part of the Town of Brookhaven, Suffolk County, N.Y. (Location is shown in pl. 1). 


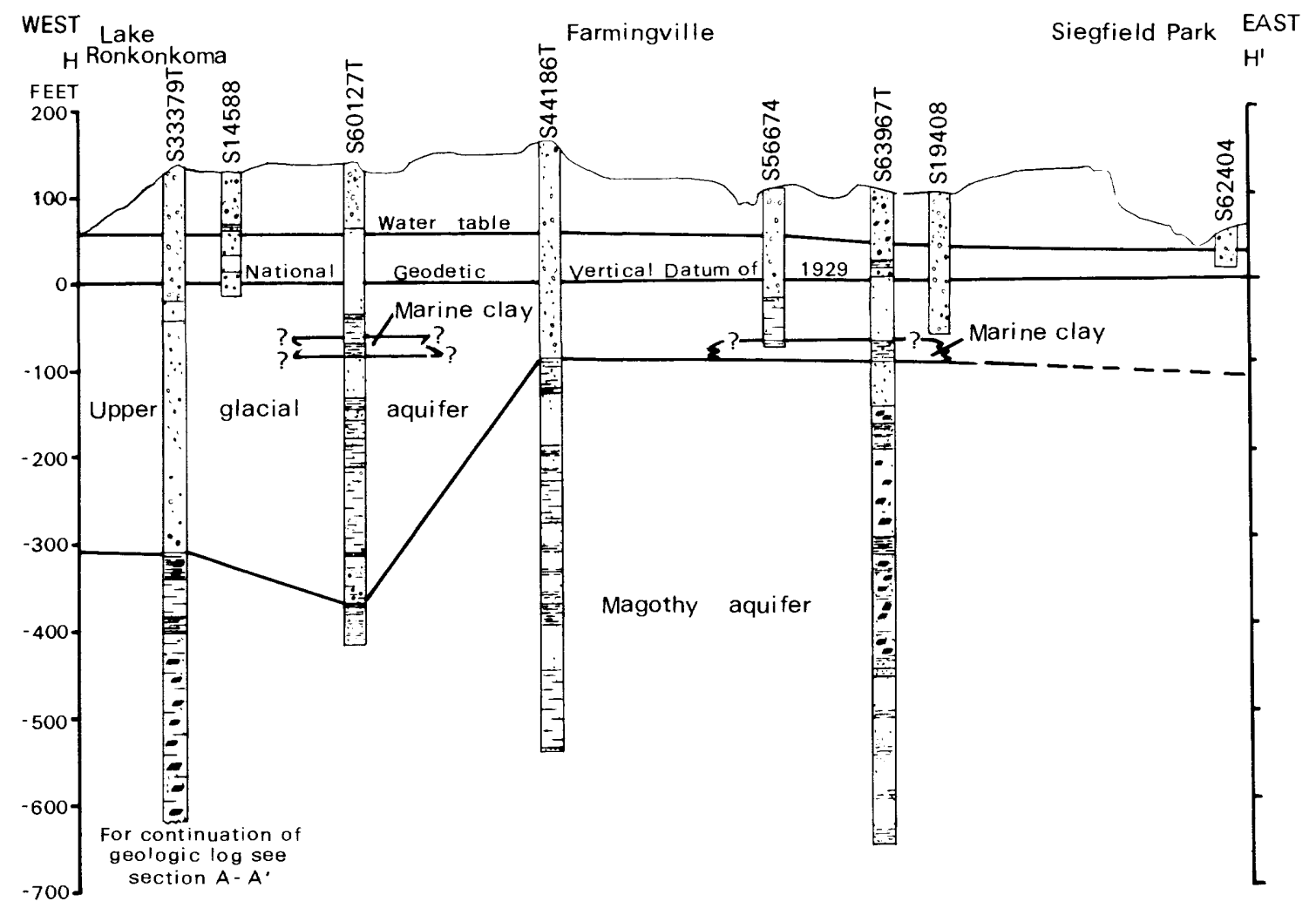

Figure 10 (continued).--Hydrogeologic section $H-H^{\prime}$, northern part of the Town of Brookhaven, Suffolk County, N.Y. (Location is shown in pl. 1). 